\title{
Revised circulation scheme north of the Denmark Strait
}

\author{
Kjetil Våge $^{\mathrm{a}, *}$, Robert S. Pickart ${ }^{\mathrm{b}}$, Michael A. Spall ${ }^{\mathrm{b}}$, G. W. K. Moore ${ }^{\mathrm{c}}$, \\ Héðinn Valdimarsson $^{\mathrm{d}}$, Daniel J. Torres ${ }^{\mathrm{b}}$, Svetlana Y. Erofeeva ${ }^{\mathrm{e}}$, and Jan Even $\emptyset$. Nilsen $^{\mathrm{f}}$ \\ ${ }^{a}$ Geophysical Institute and Bjerknes Centre for Climate Research, University of Bergen, Bergen, Norway \\ ${ }^{b}$ Woods Hole Oceanographic Institution, Woods Hole, USA \\ ${ }^{c}$ University of Toronto, Toronto, Canada \\ ${ }^{d}$ Marine Research Institute, Reykjavik, Iceland \\ ${ }^{e}$ College of Oceanic and Atmospheric Sciences, Oregon State University, Corvallis, USA \\ ${ }^{f}$ Nansen Environmental and Remote Sensing Center and Bjerknes Centre for Climate Research, Bergen, Norway
}

\begin{abstract}
The circulation and water mass transports north of the Denmark Strait are investigated using recently collected and historical in-situ data along with an idealized numerical model and atmospheric reanalysis fields. Emphasis is placed on the pathways of dense water feeding the Denmark Strait Overflow Water plume as well as the upper-layer circulation of freshwater. It is found that the East Greenland Current (EGC) bifurcates at the northern end of the Blosseville Basin, some $450 \mathrm{~km}$ upstream of the Denmark Strait, advecting overflow water and surface freshwater away from the boundary. This "separated EGC" flows southward adjacent to the previously identified North Icelandic Jet, indicating that approximately $70 \%$ of the Denmark Strait Overflow Water approaches the sill along the Iceland continental slope. Roughly a quarter of the freshwater transport of the EGC is diverted offshore via the bifurcation. Two hypotheses are examined to explain the existence of the separated EGC. The atmospheric fields demonstrate that flow distortion due to the orography of Greenland imparts significant vorticity into the ocean in this region. The negative wind stress curl, together with the closed bathymetric contours of the Blosseville Basin, is conducive for spinning up an anti-cyclonic gyre whose offshore branch could represent the separated EGC. An idealized numerical simulation suggests instead that the current is primarily eddy-forced. In particular, baroclinic instability of the model EGC spawns large anticyclones that migrate offshore and coalesce upon reaching the Iceland continental slope, resulting in the separated EGC. Regardless of the formation mechanism, the recently obtained shipboard data and historical hydrography both indicate that the separated EGC is a permanent feature of the circulation north of the Denmark Strait.
\end{abstract}

Keywords: Denmark Strait, East Greenland Current, North Icelandic Jet, Blosseville Basin, Denmark Strait Overflow Water, Arctic freshwater export

\footnotetext{
${ }^{*}$ Corresponding author.

Email address: kjetil.vage@gfi.uib.no(Kjetil Våge)
} 


\section{Introduction}

The meridional exchange across the Greenland-Scotland Ridge is of key importance for the North Atlantic climate system. Warm, saline Gulf Stream-origin waters flow northward across the ridge into the Nordic seas, release heat to the atmosphere, and are transformed into dense overflow waters. These waters return southward by flowing through gaps in the ridge as overflow plumes, which form the lower limb of the Atlantic Meridional Overturning Circulation (AMOC). As part of the horizontal circulation, fresh surface waters from the Arctic Ocean are fluxed southward along the western boundary of the Nordic seas and across the ridge. Most of this freshwater, as well as the densest portion of the AMOC - the Denmark Strait Overflow Water (DSOW) - pass between Greenland and Iceland. As such, the Denmark Strait is a critical and complex choke point in the subpolar circulation, and the pathways and water mass transports north of the strait help dictate the magnitude of the exchange between the Nordic seas and the North Atlantic Ocean.

The climatic importance of the deep overflows across the Greenland-Scotland Ridge was first hypothesized by Cooper (1955), and about a decade later remarkably accurate estimates of the overflow transports had been made (see Dickson et al., 2008, for an overview of the early measurements). The most recent observations of the DSOW near the sill indicate a mean transport of $3.4 \mathrm{~Sv}\left(1 \mathrm{~Sv}=10^{6} \mathrm{~m}^{3} / \mathrm{s}\right.$, Jochumsen et al., 2012). The first definitive scenario for the source of the DSOW was put forth by Swift et al. (1980) who suggested that the water comprising the plume originated from open-ocean convection in the central Iceland Sea (Swift and Aagaard, 1981). A later study then steered the community towards the idea that the transformation of Atlantic inflow into DSOW occurs primarily within the boundary current system of the Nordic seas (Mauritzen, 1996). This notion has persisted, supported by a recent study using over 50 years of historical hydrographic data (Eldevik et al., 2009).

Consistent with this, it was noted that Atlantic-origin water, modified by some exchange with the Greenland and Iceland seas, comprised the bulk of the overflow (Rudels et al., 2002, 2005). Geochemical tracer data suggest that the DSOW is a complex mixture of a large set of water masses originating from different regions. However, it is generally believed that Atlantic-origin water forms the major part of the overflow (Tanhua et al., 2005, 2008; Jeansson et al., 2008), with some contribution from the Iceland Sea (Olsson et al., 2005). One common link in all of these studies is that the primary pathway by which the source waters of the DSOW enter the strait is the East Greenland Current (EGC, Fig. 1). There is increasing evidence, however, that this may not be the case. 


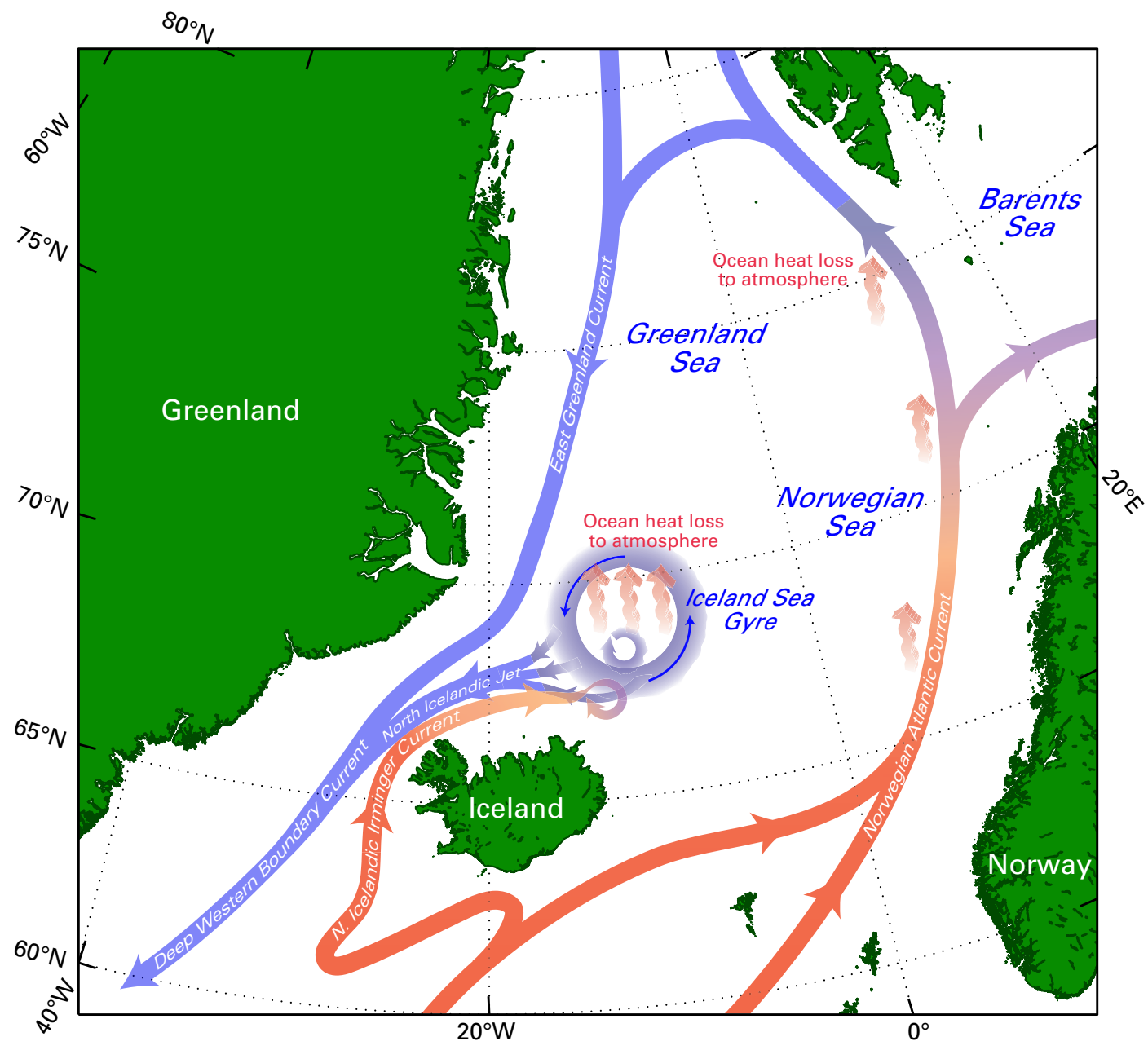

Figure 1: Two overturning circulation schemes in the Nordic seas in which warm, light surface waters (red colors) are transformed into cold, dense overflow waters (blue colors). The first scheme is the boundary current loop around the perimeter of the Nordic seas identified by Mauritzen (1996). The second scheme is the recently hypothesized interior loop north of Iceland (Våge et al., 2011b).

A previously unknown current flowing along the continental slope north of Iceland in the direction of the Denmark Strait was identified by Jónsson (1999) and Jónsson and Valdimarsson (2004), which is now referred to as the North Icelandic Jet (NIJ, Fig. 1). These studies found that the NIJ was potentially of sufficient strength to account for most of the transport of DSOW across the sill if some entrainment of ambient water was included. However, it was subsequently suggested that the NIJ is not an independent current, but rather a branch of the EGC. For example, hydraulic theory predicts that as the deep-reaching EGC approaches the Denmark Strait and encounters shoaling bathymetry, the Iceland continental slope becomes a dynamical western boundary due to the topo- 
graphic beta effect arising from the sloping bottom, forcing the EGC to cross from the Greenland side to the Iceland side (e.g. Pratt, 2004). Another possibility, present in the model simulations of Köhl et al. (2007), is that the NIJ is a branch of the EGC that bifurcates upstream of the strait as part of a time dependent process. According to their model, the total volume transport of the two branches is constant and the DSOW may be supplied by either branch.

By contrast, other model studies suggest that, at times, the NIJ may not be directly related to the EGC. Köhl (2010) argued that the magnitude of the cyclonic wind stress curl in the region dictates the source of the NIJ. In particular, when the curl is strong the NIJ originates from the EGC, but during periods of weak curl the NIJ emanates from the northern Iceland Sea. In the latter case the current stems from an offshoot of the weakening cyclonic circulation in the Iceland Sea. In some of the idealized configurations of a similar model, Käse et al. (2009) found that the NIJ can originate from a southward flow of dense water along the Jan Mayen Ridge northeast of Iceland. Such temporal switching between sources of the overflow water has also been noted in observational studies (Rudels et al., 2003; Olsson et al., 2005; Holfort and Albrecht, 2007).

A recent investigation has shed further light on the nature and source of the NIJ, which suggests that the dense current is neither a branch of the EGC nor does it originate from the northern Iceland Sea or the Jan Mayen Ridge. Data from two extensive hydrographic/velocity surveys along the Iceland slope in 2008 and 2009 imply that the NIJ advects both the densest overflow water into the Denmark Strait as well as roughly half of the total overflow transport (1.5 $\pm 0.2 \mathrm{~Sv}$, Våge et al., 2011b). Våge et al. (2011b) traced the current upstream as far as the northeast corner of Iceland, where it weakened considerably (recently collected unpublished data support this view as well). Its distinct hydrographic properties provide additional evidence that the NIJ is independent from the EGC. Using an idealized numerical simulation, Våge et al. (2011b) argued that the NIJ mainly originates along the north slope of Iceland as a deep limb of a local overturning cell whose upper branch is the North Icelandic Irminger Current (NIIC, Fig. 1), which flows northward on the eastern side of the Denmark Strait. Specifically, the warm, salty inflow is exchanged laterally with dense water transformed via air-sea interaction in the interior Iceland Sea. The dense water subsequently sinks near the boundary to form the NIJ. These results place a renewed emphasis on the Iceland Sea as a potential contributor to the AMOC.

While the transport of dense overflow water through the Denmark Strait is reasonably well quantified (Jochumsen et al., 2012), the flow of buoyant freshwater through the strait remains largely unknown. Only recently have estimates of the EGC freshwater volume transport been 
made (Holfort et al., 2008). The ability to measure this transport using moored instruments is hampered by the presence of ice. However, Holfort and Meincke (2005) successfully deployed moorings at $74^{\circ} \mathrm{N}$ east of Greenland, approximately halfway between the Fram Strait and the Denmark Strait, resulting in the first EGC total (liquid and solid) freshwater flux estimate of 40$55 \mathrm{mSv}$ (referenced to a salinity of 34.9). In the Fram Strait an extensive mooring array has been maintained since 1997, and a decade-long time series of liquid freshwater flux was recently presented by de Steur et al. (2009). Some synoptic measurements of liquid freshwater flux along the east coast of Greenland also exist (e.g. Nilsson et al., 2008; Sutherland and Pickart, 2008) as well as estimates of the solid freshwater export from the Arctic Ocean through the Fram Strait (e.g. Kwok et al., 2004).

One of the important aspects of freshwater in the high-latitude climate system is its ability to influence deep convection. However, in order to impact the convective activity in the Nordic seas and subpolar North Atlantic, there must be a flux of freshwater from the boundary current into the interior convective regions. There are two known direct export pathways of freshwater from the EGC into the Nordic seas: The Jan Mayen Current north of the Jan Mayen Fracture Zone and the East Icelandic Current north of Iceland. However, these pathways together account for only a small fraction of the freshwater flux through the Fram Strait $(15 \mathrm{mSv}$ or about 13\%, Jónsson, 2007; Dickson et al., 2007). Additional exchange between the EGC and the interior is thought to be minor (Aagaard and Carmack, 1989; Nilsson et al., 2008), leaving the bulk of the liquid freshwater to remain within the EGC (this is not necessarily the case for the solid freshwater, see Jones et al., 2008; Dodd et al., 2009, 2012). Freshwater volume transports of the EGC through the Denmark Strait have also been obtained by constructing budgets for the Nordic seas (Dickson et al., 2007; Segtnan et al., 2011), but these values represent residuals in the basin-wide balances.

While the importance of the Denmark Strait for the North Atlantic climate system is well established, the complex circulation in and upstream of the strait is not fully understood. Oceanographers have been aware of the northern overflows for a century (Nansen, 1912), yet a consensus has not been reached regarding the origin of their source waters. Closed heat and freshwater budgets for the Nordic seas will not be attainable until reliable transport measurements throughout the water column have been made in the vicinity of the strait. The motivation for the present study is to advance our understanding of the shallow and deep circulation in this critically important area. Using a collection of oceanic and atmospheric data sets, together with a numerical model, we present new aspects of the water mass pathways and dynamics in this region, with emphasis 
on the EGC system. We provide evidence of a heretofore unknown interior branch of the EGC north of the Denmark Strait that impacts the supply of both buoyant freshwater and dense overflow water to the strait. We refer to this current as the "separated EGC". Our primary objectives are to establish the existence of the separated EGC, quantify its structure and transport, and elucidate the dynamics by which it is formed, including the role of atmospheric forcing.

The structure of the paper is as follows. The various data sets and methods are presented in Section 2. We use a collection of high-resolution synoptic realizations of a hydrographic/velocity transect from Greenland to Iceland in Section 3, along with historical hydrographic data in Section 4, to investigate the circulation north of the Denmark Strait. The wind forcing is described using atmospheric reanalysis fields in Section 5. Finally, a numerical model is used in Section 6 to explore the internal and external forcing mechanisms responsible for the separated branch of the EGC and the associated interior flux of overflow water and freshwater.

\section{Data and methods}

\subsection{Synoptic sections}

Four synoptic hydrographic/velocity realizations of a transect from Greenland to Iceland across the Blosseville Basin (Fig. 2) are considered in the study. The transect, known as the Kögur section, was occupied in August 2004, October 2008, August 2011, and August 2012. Some aspects of two of the occupations have been previously presented (Sutherland and Pickart, 2008; Våge et al., 2011b). The hydrographic measurements were obtained using a Sea-Bird conductivitytemperature-depth (CTD) instrument, and velocities were measured using acoustic Doppler current profilers (ADCPs): An upward- and downward-facing lowered ADCP system in August 2012, and vessel-mounted ADCPs on the remaining cruises. The vessel-mounted ADCP instrument malfunctioned at the western end of the August 2004 occupation, and hence no velocity data were obtained on the Greenland shelf during that cruise. Vertical sections of potential temperature, salinity, potential density, and ADCP velocity for each cruise were constructed using Laplacianspline interpolation with a grid spacing of $2 \mathrm{~km}$ by $10 \mathrm{~m}$. From the temperature and salinity fields, the relative geostrophic flow normal to each section was calculated, which was then referenced by matching this to the vertically averaged ADCP velocities over the common depth interval at each horizontal grid point (Pickart et al., 2005). The accuracies of the pressure, temperature, salinity, and absolutely referenced velocity fields are estimated to be $0.3 \mathrm{dbar}, 0.001{ }^{\circ} \mathrm{C}, 0.002$, and $3.6 \mathrm{~cm} \mathrm{~s}^{-1}$, respectively. See Våge et al. (2011b) for further details of the data processing 


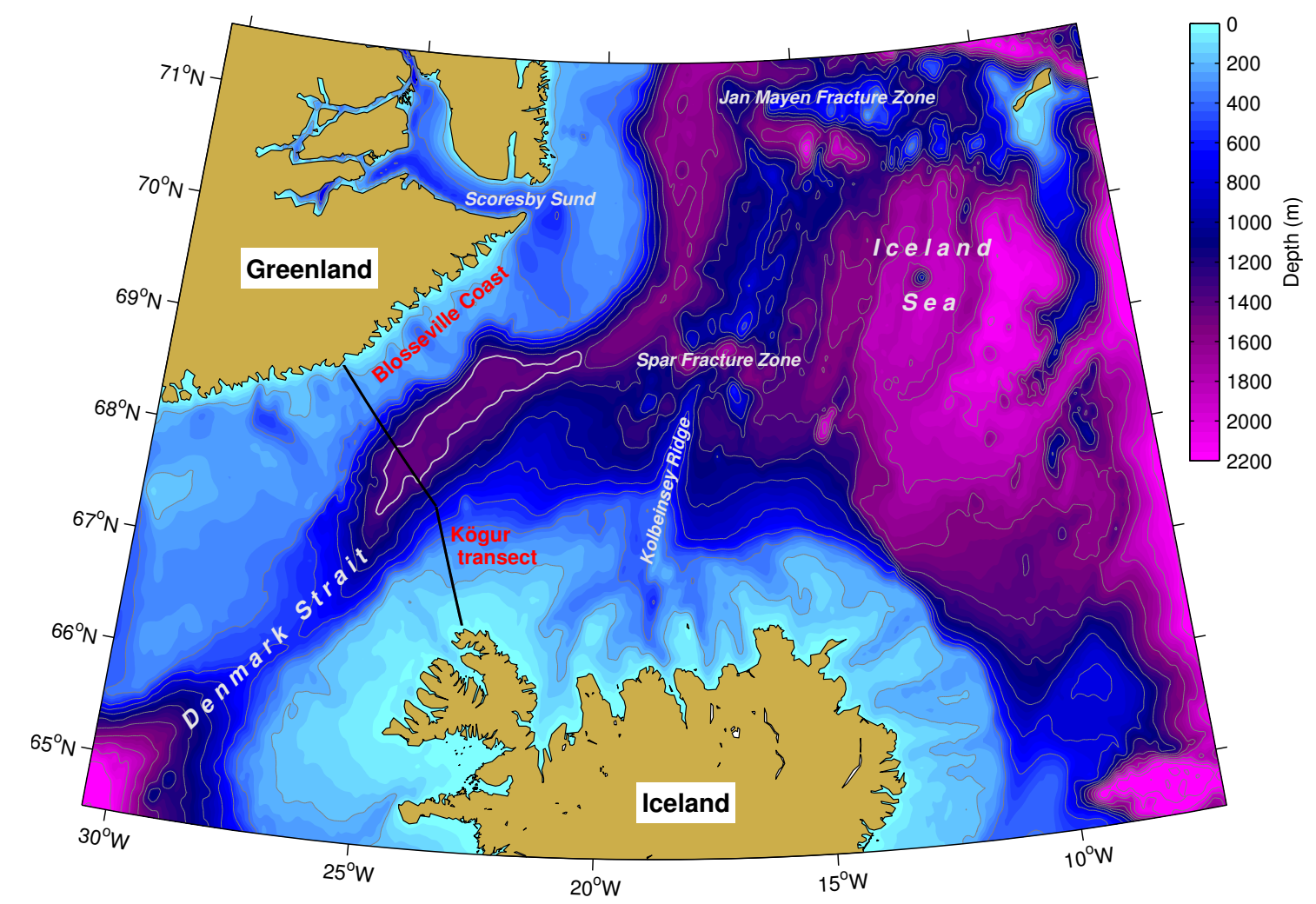

Figure 2: Bathymetry of the Iceland Sea and the Denmark Strait from the ETOPO2 2-minute elevation data base. The closed white contour is the $1400 \mathrm{~m}$ isobath roughly delineating the Blosseville Basin, and the black line identifies the Kögur transect (named after the Kögur mountain on the northwest coast of Iceland). Depth is contoured with $200 \mathrm{~m}$ increments starting at $200 \mathrm{~m}$.

and Appendix A for a description of the de-tiding procedure and the methodology for calculating transports, including errors.

\subsection{Historical hydrography}

The historical hydrographic data employed in this study cover the period from 1980 to the present and were acquired from the archives of the Marine Research Institute of Iceland, the International Council for the Exploration of the Seas (ICES), the World Ocean Database, the Norwegian Iceland Seas Experiment (NISE) database (Nilsen et al., 2008), and the Argo global program of profiling floats (using only delayed-mode data, which have been corrected for drift in the conductivity and pressure sensors, Wong et al., 2003). The profiles from these different sources were combined into a single product, hereafter referred to as the historical hydrographic data set. Only observations obtained during the summer half-year period of May through October (66\% of the 
total number of measurements) are considered here due to a dearth of wintertime data on the Greenland continental shelf and slope. See Appendix B for details of the quality control and gridding of the historical hydrography.

\subsection{Meteorological fields}

We employ two different reanalysis products in this work. The Interim Reanalysis (ERA-I) from the European Center for Medium Range Weather Forecasts is a global product (Dee et al., 2011). We use the $0.75^{\circ}$ interpolated 6-hourly fields for the period from January 1979 to December 2011. Comparison with aircraft and ship observations in the southeast Greenland region show good agreement with ERA-I (Renfrew et al., 2009; Harden et al., 2011).

For a higher resolution view of the surface wind field in the region of interest, we also make use of the North American Regional Reanalysis (NARR) from the U.S. National Meteorological Center (Mesinger et al., 2006). The NARR is a regional dataset that covers the North American continent as well as adjoining oceanic regions including southeast Greenland and the Irminger Sea, with lateral boundary conditions provided by the NCEP-2 global reanalysis. The NARR has a horizontal resolution of approximately $32 \mathrm{~km}$. For this paper we use the full 3-hourly resolution data set for the period from January 1979 to December 2011. Recent studies of the flow distortion around the topography of southern Greenland indicate that the NARR surface fields are in good overall agreement with both aircraft and buoy observations (Moore et al., 2008; Renfrew et al., 2009).

\subsection{Idealized simulations}

A high-resolution regional general circulation model is implemented to aid in the interpretation of the observational results and to provide insights on the dynamics of the circulation. The model is the MITgcm (Marshall et al., 1997), which solves the hydrostatic primitive equations of motion on a fixed Cartesian, staggered C-grid in the horizontal and at constant depths in the vertical. Bottom topography is treated with a partial cell, which provides a high-resolution representation of the bottom topography while retaining accuracy in the calculation of the horizontal pressure gradient (Adcroft et al., 1997). The model uses a linear equation of state $\rho=\rho_{0}+\beta\left(S-S_{0}\right)$, where $\beta=0.8 \mathrm{~kg} \mathrm{~m}^{-3}, \rho_{0}=1026.5 \mathrm{~kg} \mathrm{~m}^{-3}$ is a reference density, and $S_{0}=32.5$ a reference salinity. For simplicity, only salinity is considered (temperature is constant).

The model domain is a channel oriented along the east coast of Greenland, extending $864 \mathrm{~km}$ in the along-boundary direction, $\mathrm{y}$, and $480 \mathrm{~km}$ in the offshore direction, $\mathrm{x}$ (Fig. 3, rotated counterclockwise by $33^{\circ}$ ). The Coriolis parameter is $f=1.3 \times 10^{-4} s^{-1}$, taken to be constant. The 


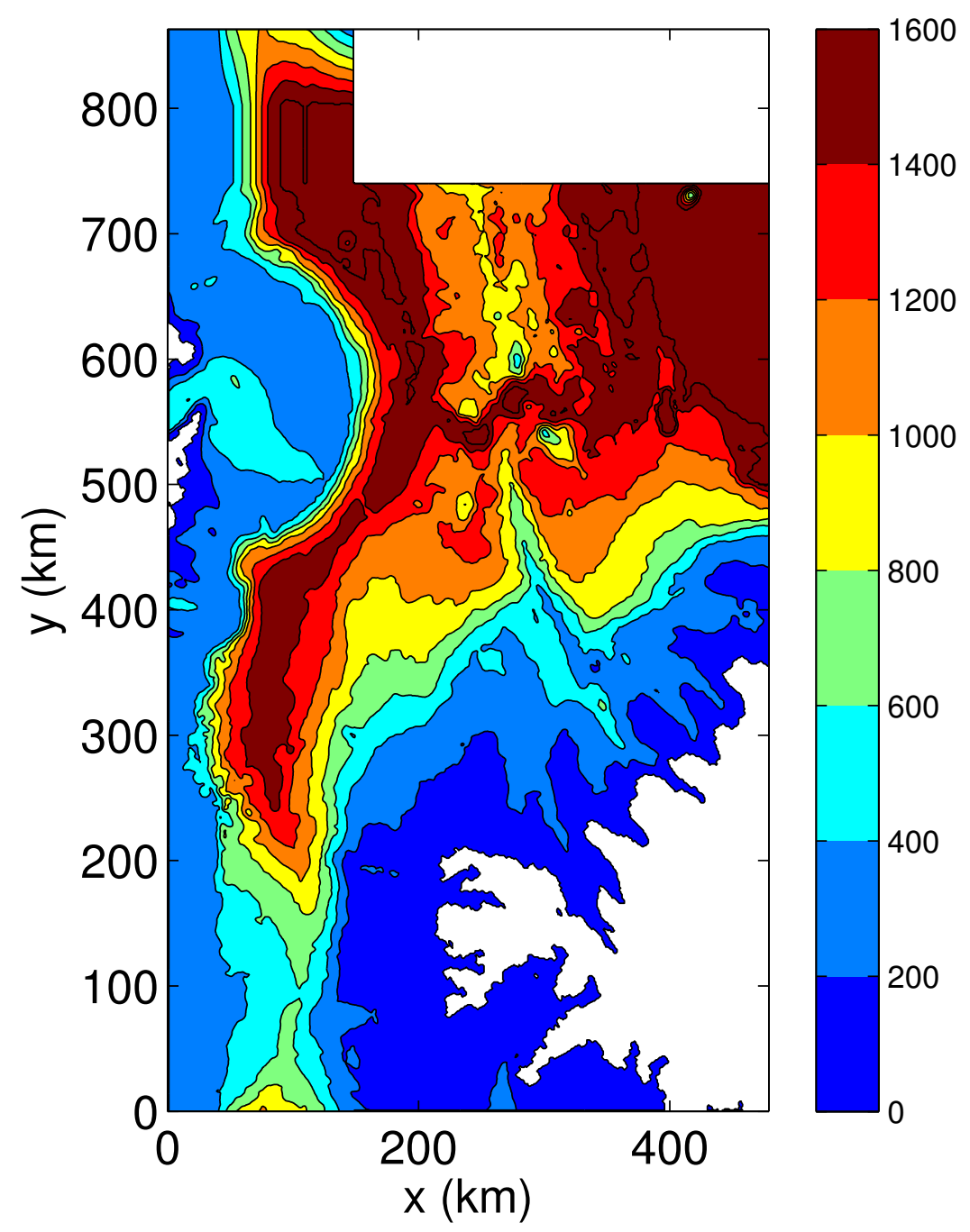

Figure 3: Model domain and bottom topography. The white regions are land.

bottom topography has been linearly interpolated to the model grid from the ETOPO2 2-minute elevation data base and then smoothed with a 5-point filter. The model is initialized with fresh, stratified water on the shelf (bottom depths shallower than $400 \mathrm{~m}$ ) with a minimum salinity of 32 at the surface, which varies exponentially with vertical scale of $250 \mathrm{~m}$ towards a deep salinity of 35. The basin interior (bottom depths greater than $575 \mathrm{~m}$ ) is filled with unstratified water with a salinity of 35. The salinity at each depth in the transition region between 400 and $575 \mathrm{~m}$ bottom depth is linearly interpolated between the shelf and interior values at each depth. The stratification in the region between 740 and $840 \mathrm{~km}$ in $\mathrm{y}$ and the region offshore of $350 \mathrm{~km}$ in $\mathrm{x}$ are restored towards this initial state with a time scale of 5 days. This provides a source of freshwater on the 
shelf and saline water in the basin interior. The long-time evolution is not qualitatively sensitive to the details of the initial profile, provided that freshwater is initialized over the shelf. The bottom topography in the region between 804 and $864 \mathrm{~km}$ is linearly interpolated from the value at $\mathrm{y}=0$ to that at $y=804 \mathrm{~km}$. In this way, the flow out of the southern end of the channel provides the inflow from the north and mass is conserved, while the restoring of salinity maintains freshwater on the shelf. The region offshore of this northern restoring region is a solid boundary, provided to prevent large-scale recirculations in the interior. The offshore boundary of the model is placed far from the region of interest, and salinity restoring for $\mathrm{x}>350 \mathrm{~km}$ is used to minimize influences of Ekman transport interacting with the solid eastern boundary.

The horizontal resolution of the model is $1 \mathrm{~km}$ in both the $\mathrm{x}$ and $\mathrm{y}$ directions. There are 30 levels in the vertical, with grid spacing increasing from $5 \mathrm{~m}$ over the upper $20 \mathrm{~m}$ to $250 \mathrm{~m}$ near the bottom. The maximum bottom depth is approximately $1500 \mathrm{~m}$. The model incorporates second order vertical viscosity and diffusivity with coefficients of $10^{-5} \mathrm{~m}^{2} \mathrm{~s}^{-1}$. Horizontal viscosity is parameterized as a second order operator with the coefficient $A_{h}$ determined by a Smagorinsky closure as

$$
A_{h}=(\nu / \pi)^{2} \Delta^{2} D
$$

where $\Delta$ is the grid spacing, and $D$ is the deformation rate defined as $D=\left[\left(u_{x}-v_{y}\right)^{2}+\left(u_{y}+\right.\right.$ $\left.\left.v_{x}\right)^{2}\right]^{1 / 2}, u$ and $v$ are the horizontal velocities, subscripts indicate partial differentiation, and $\nu=1$. There is no explicit diffusion of salinity.

\section{Synoptic transects north of the Denmark Strait}

The Kögur transect (Fig. 2) extends from Greenland to Iceland across the Blosseville Basin, hence capturing all of the advective pathways into the Denmark Strait. The transect is sufficiently far upstream that distinct deep pathways can be distinguished prior to forming the merged DSOW plume that subsequently overflows the sill. To investigate the conditions north of the strait, we first examine the mean flow patterns and hydrography, and then inspect the individual realizations in more detail. Finally, transport estimates for each pathway are presented.

\subsection{Mean velocity structure}

The EGC flows southward from the Fram Strait, roughly paralleling the east Greenland shelf break, as part of the cyclonic boundary current system transiting the perimeter of the Nordic seas. Freshwater exported from the Arctic in the form of Polar Surface Water (PSW, see Rudels et al. 


\footnotetext{
${ }^{1}$ From here on we use the term shelf break EGC to distinguish the EGC from the separated EGC in the Blosseville Basin.
} 

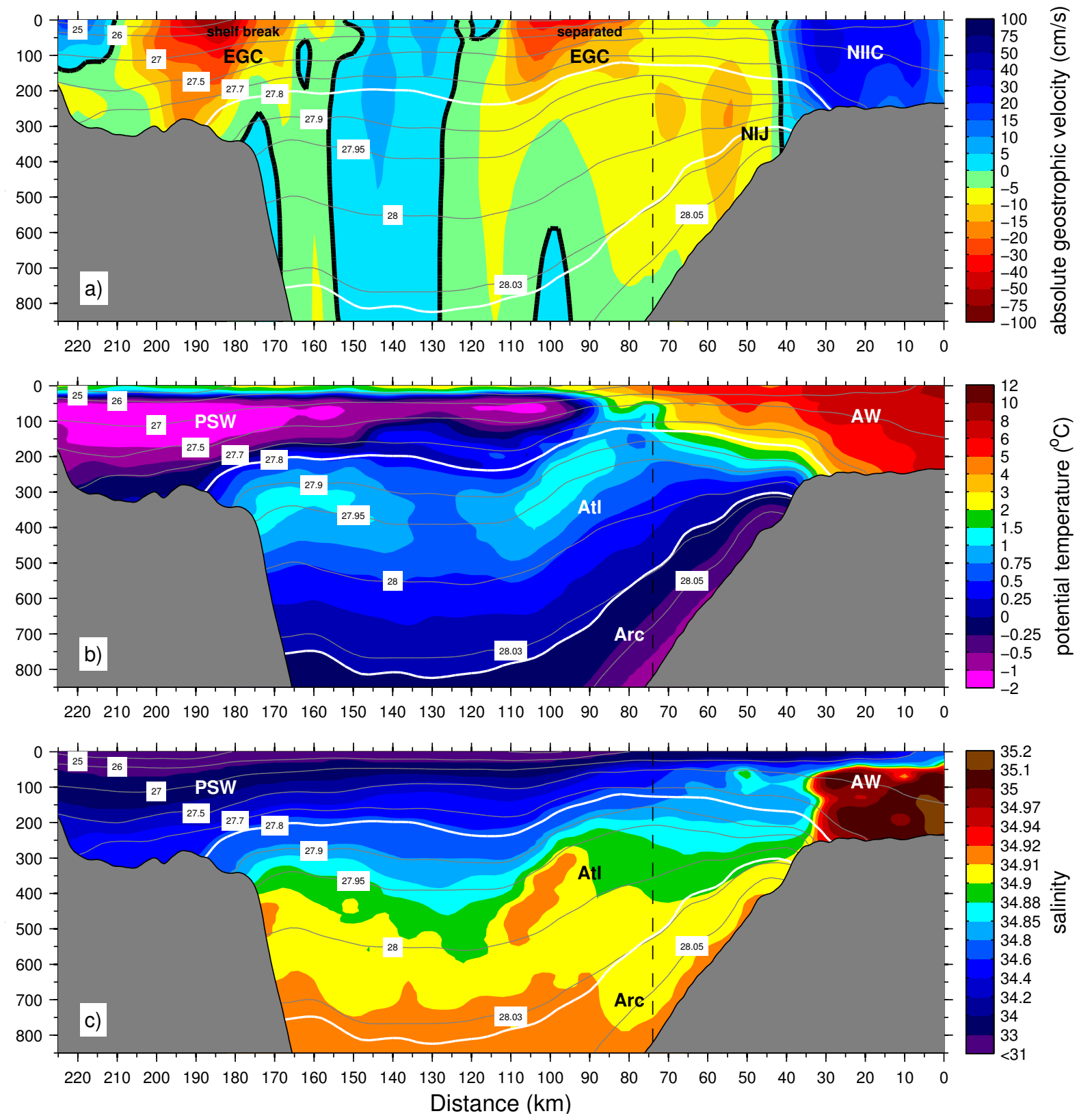

Figure 4: Mean vertical sections along the Kögur transect. (a) Absolutely referenced geostrophic velocity (color, $\mathrm{cm} / \mathrm{s}$, equatorward flow is negative), overlain by potential density (thin gray contours, $\mathrm{kg} / \mathrm{m}^{3}$ ). The $27.8 \mathrm{~kg} / \mathrm{m}^{3}$ isopycnal and the $0^{\circ} \mathrm{C}$ isotherm are highlighted in white. The dashed vertical line indicates the boundary between the separated EGC and the NIJ. The thick black line in (a) is the zero velocity contour. The acronyms are: EGC = East Greenland Current; NIJ = North Icelandic Jet; NIIC = North Icelandic Irminger Current; PSW = Polar Surface Water; AW = Atlantic Water; Atl = Atlantic-origin overflow water; Arc = Arctic-origin overflow water. (b) Potential temperature (color, ${ }^{\circ} \mathrm{C}$ ) and (c) Salinity (color). 
is the NIIC, which is the poleward extension of the Irminger Current. It advects warm, saline Atlantic Water (AW) northward through the Denmark Strait in the vicinity of the shelf break, and influences the climate and ecosystem north of Iceland (e.g. Jónsson and Valdimarsson, 2012b). The NIIC is also believed to be the surface component of a regional overturning loop whose lower branch consists of Arctic-origin overflow water transformed within the central Iceland Sea and transported equatorward by the NIJ (Fig. 1; Våge et al., 2011b).

\subsection{Mean hydrographic structure}

In the mean Kögur section, cold, fresh PSW dominates the upper water column on the Greenland shelf. This water mass extends far offshore into the interior of the Blosseville Basin, more than halfway across the transect (Fig. 4b, c). Warm, saline AW is found over the Iceland shelf and slope.

Below the surface layer, water denser than $\sigma_{\theta}=27.8 \mathrm{~kg} / \mathrm{m}^{3}$ (the upper white contour in Figure 4) has traditionally been identified as overflow water (e.g. Dickson and Brown, 1994). Following Våge et al. (2011b), we distinguish two types of overflow water: Atlantic- and Arctic-origin overflow waters, warmer and colder than $0^{\circ} \mathrm{C}$, respectively (the $0^{\circ} \mathrm{C}$ contour is highlighted white in Figure 4). These names refer to the geographic domain in which the transformation from surface to overflow water takes place (Swift and Aagaard, 1981). The Atlantic-origin overflow water is identified by an intermediate maximum in temperature and salinity, and is primarily found between the 27.9 and $28.0 \mathrm{~kg} / \mathrm{m}^{3}$ isopycnals. In the mean Kögur transect this layer extends from the Greenland continental slope and shoals towards the surface front of the separated EGC. Two cores of Atlantic-origin overflow water, near 100 and $170 \mathrm{~km}$, appear to be associated with the separated EGC and the shelf break EGC, respectively. On the eastern side of the Kögur section the Arctic-origin overflow water is banked up high on the Iceland continental slope. This forms the densest component of the DSOW plume (generally denser than $28.03 \mathrm{~kg} / \mathrm{m}^{3}$ ), and is primarily supplied by the NIJ (Våge et al., 2011b).

The PSW and Atlantic-origin overflow water are generally associated with the EGC and hence largely confined to the Greenland shelf and slope (this is particularly true for the shallow waters, Aagaard and Carmack, 1989; Nilsson et al., 2008). However, our data reveal that, associated with the separated EGC, these water masses are clearly found in the interior of the Blosseville Basin as well (Fig. 4b, c). Regardless of the process by which the separated EGC is formed, this current provides another means of shelf-basin exchange in addition to the direct advective pathways represented by the Jan Mayen Current and the East Icelandic Current. 


\footnotetext{
${ }^{2}$ This provides justification for computing a mean section based only on four realizations.
}

\subsection{Temporal variability}

The major flow features present in the mean Kögur transect - the two branches of the EGC, the NIJ, and the NIIC - are evident as well in each of the individual realizations (Fig. 5). ${ }^{2}$ On the western side of the transect one sees the shelf break EGC, although it is variable in magnitude from section to section. This is likely due in part to the strength of the wind forcing. For example, in October 2008 the shelf break EGC was quite strong because it was under the influence of northerly winds, while in August 2012 the winds were predominantly from the south, which likely resulted shelf break EGC, which carries the overflow water, seems to vary both in strength and in lateral position in the individual realizations.

On the eastern side of the Kögur section the NIIC was sampled on three occasions (the August 2011 occupation did not extend onto the Iceland continental shelf), evident as a surface-intensified poleward flow. In October 2008 and August 2012 the current was located near the shelf break, while in August 2004 it was found farther inshore on the shelf. Seaward of this, in all four realizations, the NIJ was situated near the $650 \mathrm{~m}$ isobath, which is also the depth of the Denmark Strait sill. This is consistent with the results of Våge et al. (2011b) who demonstrated that the NIJ feeds the DSOW. At times the NIJ consisted of distinct filaments of equatorward flow, the reasons for which remain unclear. However, we note that the NIJ's characteristic isopycnal divergence and mid-depth intensification were present in each realization. resides at the hydrographic front where the bulk of the PSW layer ends. As is true for the shelf break branch of the EGC, the lateral salinity gradient dominates the temperature gradient, resulting in a density front that supports a surface-intensified southward-flowing jet. One sees that the penetration depth of the separated EGC can be quite extensive. Interestingly, the first two realizations In those two cases there is a well-defined deep-reaching poleward flow to the west that could be construed as the northward branch of the gyre. By contrast, the latter two realizations of the trancentered at $105 \mathrm{~km}$ in the 2011 occupation (Figs. 6c and 7c), corresponding to an anti-cyclonic in the poleward flow at depth that "split" the shelf break EGC in two. The deep extension of the

Seaward of the NIJ, in the eastern part of the Blosseville Basin over the deep Iceland continental slope, the separated EGC is present in each occupation of the Kögur transect. This current of the Kögur section (2004 and 2008) are more reminiscent of the above-mentioned gyre scenario. sect (2011 and 2012) suggest the presence of eddies. In particular, note the lens of cold PSW 


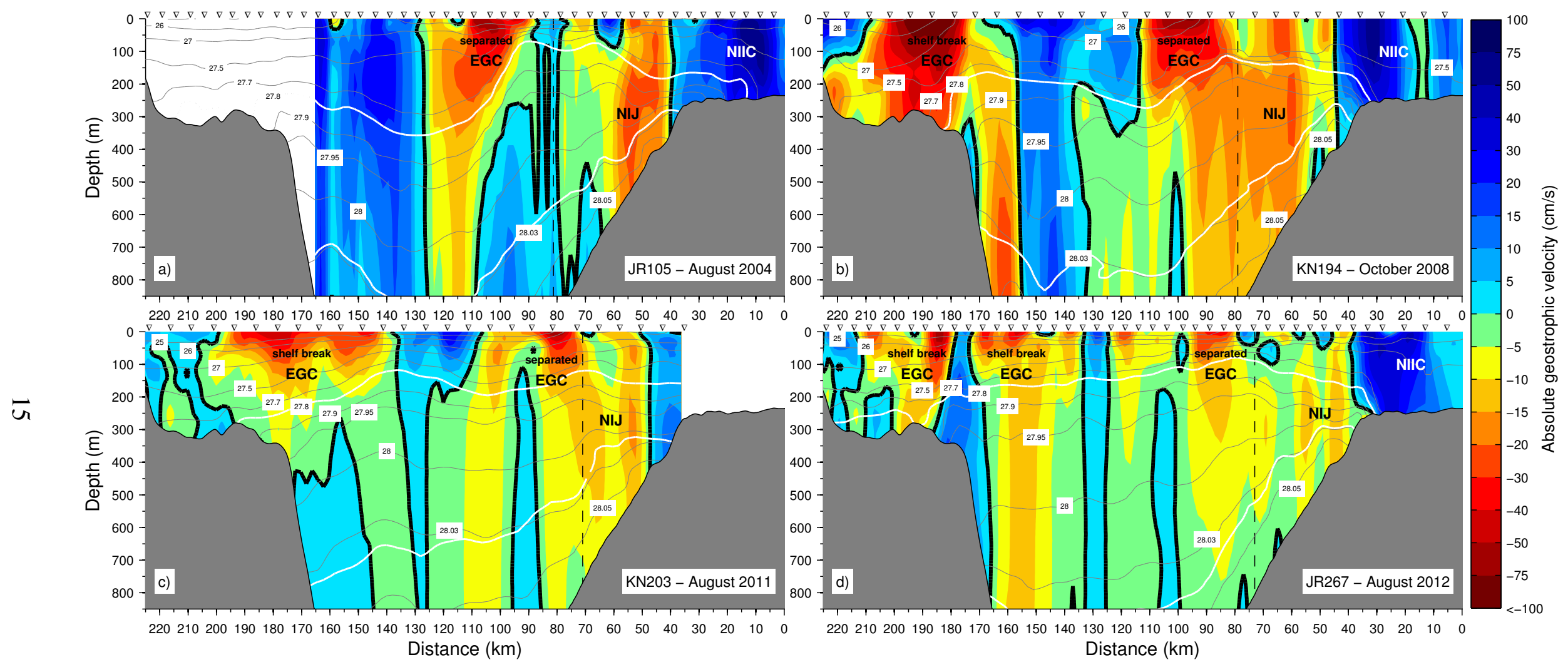

Figure 5: Vertical sections along the Kögur transect of absolute geostrophic velocity (color, cm/s, equatorward flow is negative) overlain by potential density (contours, $\mathrm{kg} / \mathrm{m}^{3}$ ). The panels show the (a) August 2004, (b) October 2008, (c) August 2011, and (d) August 2012 realizations. The $27.8 \mathrm{~kg} / \mathrm{m}^{3}$ isopycnal and the $0^{\circ} \mathrm{C}$ isotherm are highlighted in white. The dashed vertical line indicates the approximate boundary between the separated EGC and the NIJ. The black line is the zero velocity contour. 


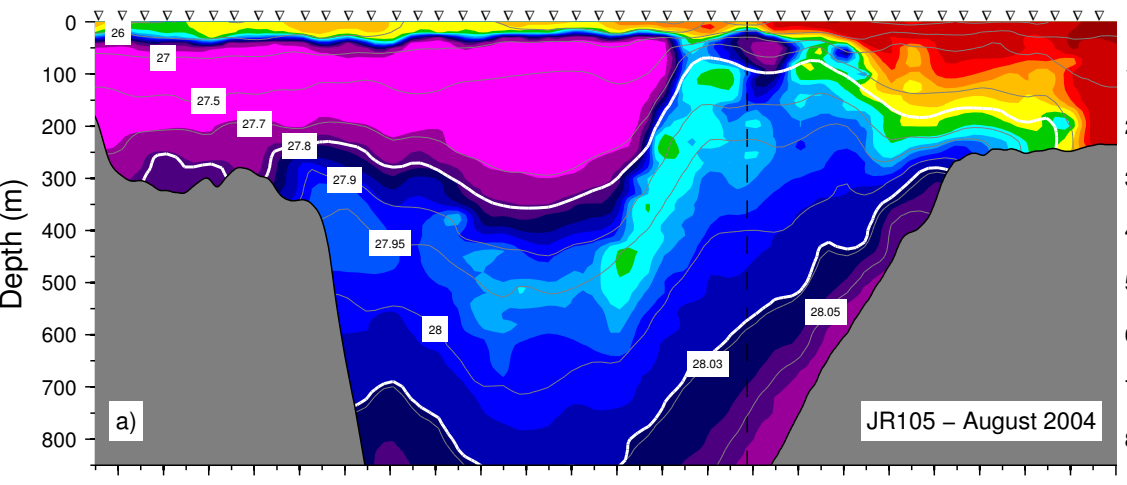

$\bar{\sigma}$
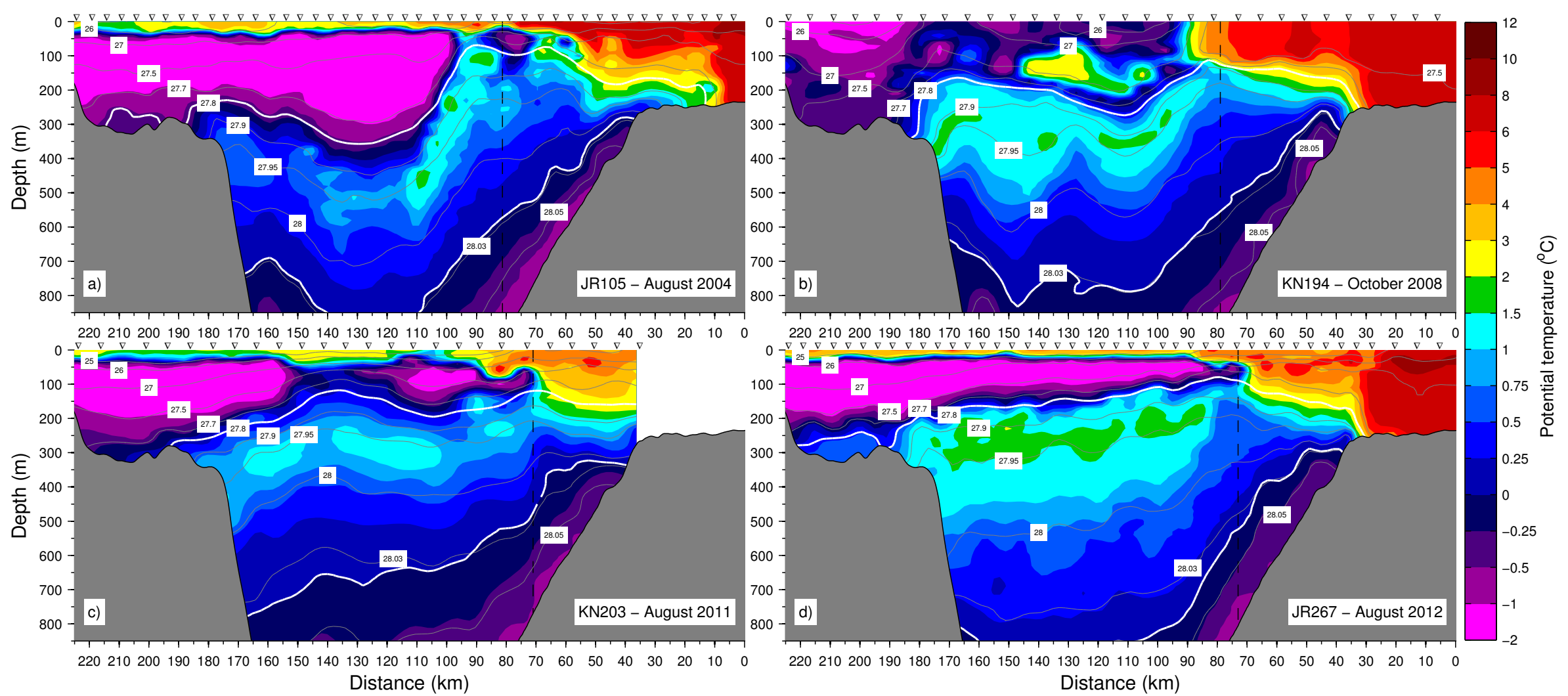

Figure 6: Same as Figure 5, but for potential temperature (color, ${ }^{\circ} \mathrm{C}$ ). 

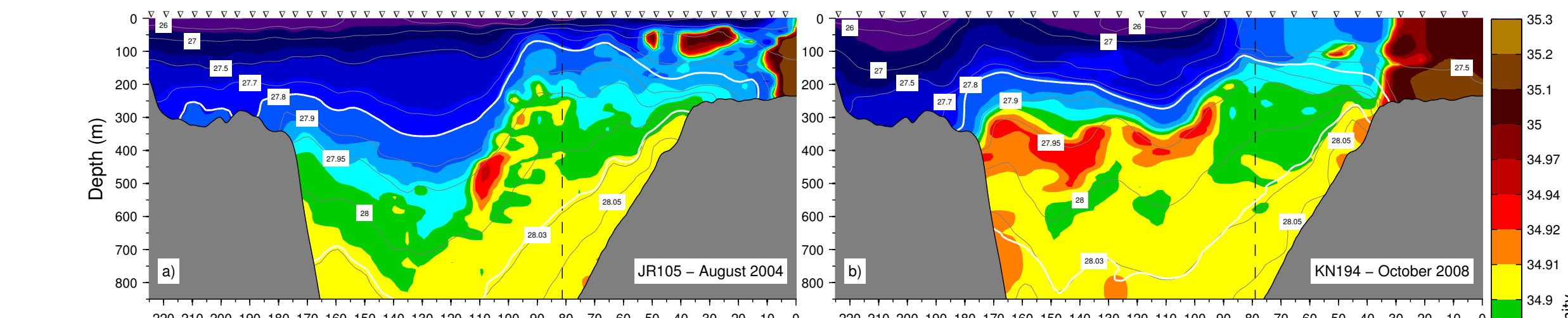

$\Xi$
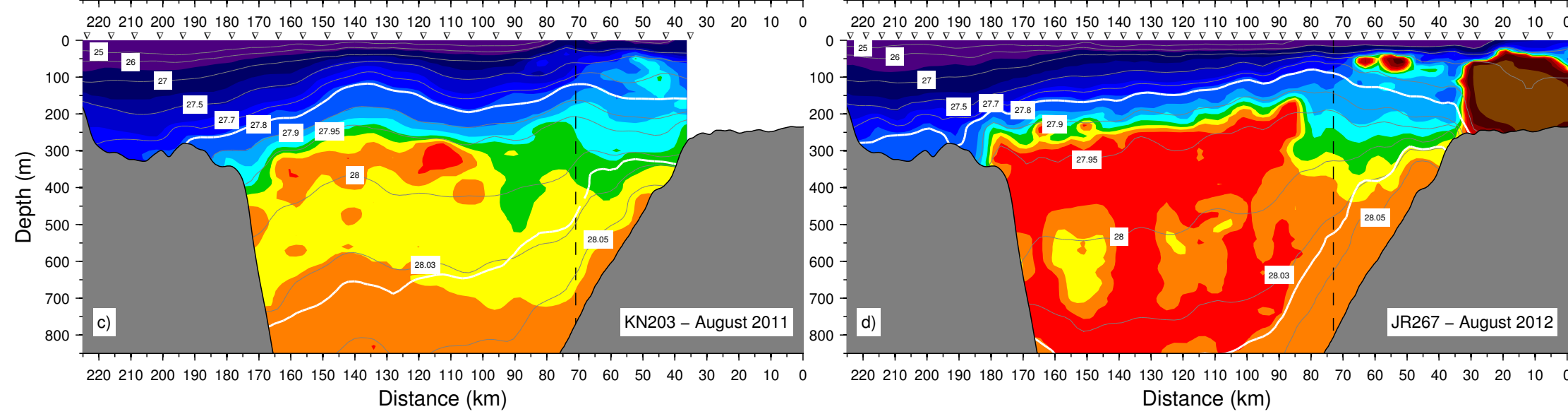

$220210200190180170160150140130120110100 \quad 90 \quad 80 \quad 70 \quad 60 \quad 50 \quad 40 \quad 30 \quad 20 \quad 10$ Distance $(\mathrm{km})$

Figure 7: Same as Figure 5, but for salinity (color). 
surface-intensified circulation (Fig. 5c). This is indicative of a large eddy that might have been shed from the shelf break EGC. These two scenarios, eddy-forced vs. wind-forced, are elaborated on later in the paper.

\subsection{Transports}

We now document the volume transport, and, where appropriate, the freshwater transport of each of the equatorward currents present in the Kögur transect. This demonstrates the importance of the NIJ as well as the separated EGC - both newly revealed features - in the circulation system north of the Denmark Strait. Averaged over all four realizations, the shelf break EGC transported $108 \pm 24 \mathrm{mSv}$ and the separated EGC $29 \pm 7 \mathrm{mSv}$ of freshwater relative to a reference salinity of 34.8 (Fig. 8a). Hence, nearly one quarter of the total freshwater transport within the EGC system takes place in the interior of the Blosseville Basin, which must be considered in order to obtain accurate estimates of the freshwater export through the Denmark Strait. Most $(>95 \%)$ of this freshwater transport takes place within the upper $200 \mathrm{~m}$ of the water column, while a negligible amount is transported by the NIJ.

There have been no mooring-based estimates of liquid freshwater transport in the vicinity of the Denmark Strait because of the inherent risks due to pack-ice and icebergs. As such, the most relevant numbers for comparison were obtained assuming balanced Nordic seas freshwater budgets. Relative to reference salinities of 35.2 and 34.9, Dickson et al. (2007) and Segtnan et al. (2011) computed freshwater fluxes through the Denmark Strait of 151 and $130 \mathrm{mSv}$, respectively. Our corresponding numbers for the composite EGC are $223 \pm 37 \mathrm{mSv}$ and $159 \pm 28 \mathrm{mSv}$. While the estimates of Dickson et al. (2007) and Segtnan et al. (2011) are total freshwater flux (liquid and solid), only small amounts of sea ice were encountered during our realizations, hence it is reasonable to compare our estimates with the earlier studies. The volume transport of water lighter than $\sigma_{\theta}=27.8 \mathrm{~kg} / \mathrm{m}^{3}$ across the Kögur transect is $2.6 \pm 0.3 \mathrm{~Sv}$ in the shelfbreak EGC and $1.3 \pm 0.1 \mathrm{~Sv}$ in the separated EGC. The combined transport is substantially larger than the $1.3 \mathrm{~Sv}$ of surface outflow in the EGC reported by Hansen and Østerhus (2000).

The hydrographic analysis of Mauritzen (1996) suggested that the main path of overflow water into the Denmark Strait is along the continental slope of east Greenland via the EGC. Our results imply instead that the majority of the overflow water approaches the strait from the Iceland continental slope through a combination of the NIJ and the separated EGC. While this is consistent with predictions from hydraulic theory (e.g. Pratt, 2004), we will show in Sections 5 and 6 that the separated EGC has not simply switched to the Iceland side due to shoaling bathymetry of the 

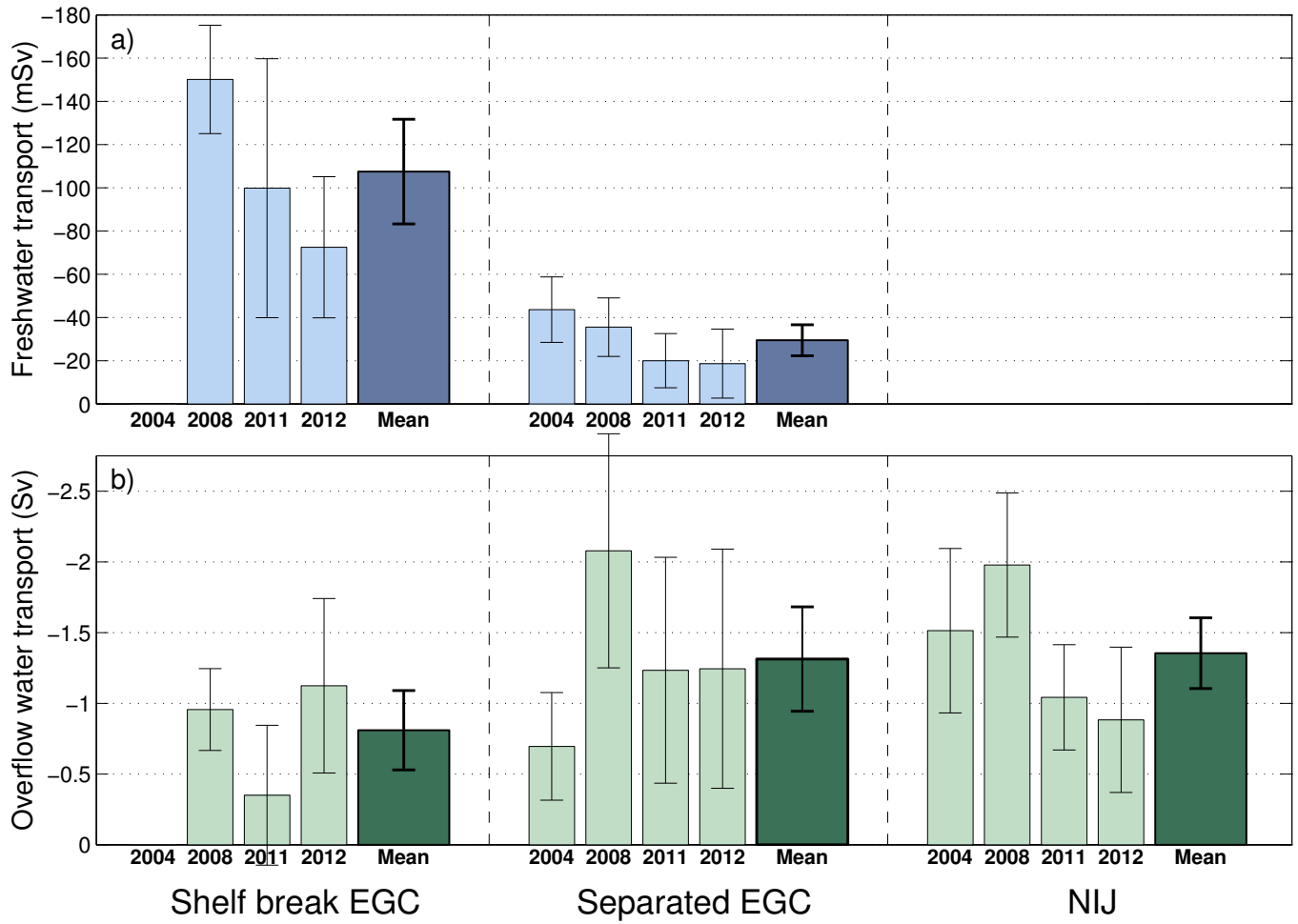

Figure 8: Transport estimates across the Kögur transect (equatorward flow is negative) for the shelf break EGC (left), the separated EGC (middle), and the NIJ (right). Panel a) shows freshwater transports (relative to a reference salinity of 34.8), and panel b) shows overflow water transports $\left(\sigma_{\theta} \geq 27.8 \mathrm{~kg} / \mathrm{m}^{3}\right.$ and depth $<650 \mathrm{~m}$ ). The thin bars represent the 4 realizations and the thick bar is the mean value. The black lines are error bars.

strait. Furthermore, Våge et al. (2011b) have previously documented that the NIJ originates along the Iceland continental slope far upstream of the Denmark Strait. Hence the topographic beta effect does not seem to play an important role in the pathways of dense water leading to the sill. Our calculated average overflow water transports $\left(\sigma_{\theta} \geq 27.8 \mathrm{~kg} / \mathrm{m}^{3}\right.$ and depth $\left.<650 \mathrm{~m}\right)$ are $0.8 \pm 0.3 \mathrm{~Sv}$ in the shelf break EGC, $1.3 \pm 0.4 \mathrm{~Sv}$ in the separated EGC, and $1.4 \pm 0.3 \mathrm{~Sv}$ in the NIJ (Fig. 8b). The combined sum of $3.5 \mathrm{~Sv}$ corresponds well with the long-term mean overflow water transport through the Denmark Strait of 3.4 Sv estimated by Jochumsen et al. (2012), and our NIJ overflow water transport is in good agreement with the previous estimate of $1.5 \pm 0.2 \mathrm{~Sv}$ from two synoptic surveys (Våge et al., 2011b).

In the gyre scenario outlined above, some of the equatorward transport of freshwater and overflow water in the separated EGC would recirculate before reaching the Denmark Strait sill. The poleward return flow is weaker, however, resulting in a net equatorward throughput. Based on the present set of sections, the poleward return flow is approximately half of the equatorward flow in 
the separated EGC. Even if no permanent gyre exists in the Blosseville Basin, the synoptic sections indicate that there is some transient northward flow between the shelf break EGC and the separated EGC. This would tend to reduce the composite EGC contribution to the total overflow transport, although this smaller total transport is still in good agreement with the value calculated by Jochumsen et al. (2012) when considering measurement errors. The northward flow would similarly tend to reduce the composite EGC freshwater transport, but the resulting net throughput is still higher than the previous calculations that assume a balanced Nordic seas freshwater budget. It is worth noting that sparse measurements on the inner Greenland shelf indicate that the freshest water is found adjacent to the coast, possibly associated with a southward flow. Such a coastal current could have a significant freshwater transport, but this cannot be properly assessed with the present set of sections.

The poleward flow of AW through the Denmark Strait in the NIIC has been monitored for a number of years using moorings located roughly $80 \mathrm{~km}$ to the east of the Kögur transect. The long-term mean transport at that location (known as the Hornbanki line) is $0.88 \mathrm{~Sv}$ (Jónsson and Valdimarsson, 2012b). Delineating the $\mathrm{AW}$ by a salinity greater than 34.9 and temperature warmer than $3^{\circ} \mathrm{C}$ (after Swift and Aagaard, 1981), we obtain a three-section mean NIIC transport of $1.1 \pm 0.2 \mathrm{~Sv}$. AW is the only warm and saline water mass along the Kögur transect (Fig. 4), and the transport estimate is not very sensitive to the precise criteria used. Our larger value of NIIC transport may be due to synoptic variability, or there may be leakage of AW from the NIIC between the two locations (Jónsson and Valdimarsson, 2005). On the other hand, the mooring-derived value at the Hornbanki line could be an underestimate due to inadequate spatial coverage (Jónsson and Valdimarsson, 2012b).

The process of aspiration, by which dense water upstream of a ridge is raised above sill level to participate in an overflow, is believed to occur in the Strait of Gibraltar and in the Faroe Bank Channel (Stommel et al., 1973; Kinder and Parrilla, 1987; Hansen and Østerhus, 2007). In our occupations of the Kögur line the geostrophic velocities are generally weak at depths greater than the Denmark Strait sill. In fact, the mean transport below $650 \mathrm{~m}$ is not significantly different from zero. This implies that aspiration is not important in the Denmark Strait. There was, however, considerable variability in the deep flow from section to section (not shown). 


\section{Historical hydrography north of the Denmark Strait}

The synoptic sections presented above reveal that the EGC has two branches north of the Denmark Strait, and, accordingly, PSW occupies much of the interior Blosseville Basin. Furthermore, a significant fraction of the Atlantic-origin overflow water is transported by the separated EGC. We now use the historical hydrographic data set to demonstrate that our results are consistent with previous measurements. The dynamic topography of the sea surface relative to $500 \mathrm{~m}$ is shown in Figure 9, which reveals features of the upper ocean circulation in the region. The broad minimum in the central Iceland Sea indicates the presence of a cyclonic gyre, and is consistent with earlier findings using a more sparse hydrographic data set (Swift and Aagaard, 1981) and direct velocity measurements (Voet et al., 2010). In the northwest part of the domain, along the east Greenland shelf break (marked by the gray contour following the $500 \mathrm{~m}$ isobath in Figure 9), a sharp increase in dynamic height is evident which implies surface-intensified equatorward flow. This is the shelf break EGC. However, at the northern end of the Blosseville Basin near $69^{\circ} \mathrm{N}$ the high values of dynamic topography extend into the interior. Here the separated EGC splits from the shelf break EGC. Farther south, over the length of the Blosseville Basin (marked by the closed gray contour following the $1400 \mathrm{~m}$ isobath in Figure 9), the two branches can be identified by regions of enhanced gradients in dynamic topography: Along the Greenland shelf break, and in the interior along the base of the Iceland continental slope. Interestingly, a consistent northward return flow is not visible in the mean map of dynamic topography. If it exists, it may not appear in the mean due to a weaker baroclinic signature than the surface-intensified separated EGC (see Figure 4) or due to sparse data in the western Blosseville Basin. We note that inspection of along-track altimeter sea surface height also does not reveal a northward flow, but this product is not expected to perform well in partially ice-covered waters and on such small spatial scales.

The distribution of polar waters north of the Denmark Strait closely resembles the dynamic topography. Near-surface potential temperature and salinity fields (Fig. 10) show that the PSW is closely confined to the shelf north of $69^{\circ} \mathrm{N}$, whereas in the Blosseville Basin this water mass spreads far into the interior to the base of the Iceland slope. (A slightly deeper level is considered for temperature than for salinity in order to avoid the summertime surface warming due to insolation, evident in Figure 4.) Presence of PSW over the deep Iceland slope is regularly observed at the Kögur transect, and some of this water mass is likely mixed into the AW transported by the NIIC along the shelf north of Iceland (Jónsson and Valdimarsson, 2012b).

While PSW was confined to the Greenland shelf north of $69^{\circ} \mathrm{N}$, the Atlantic-origin overflow 


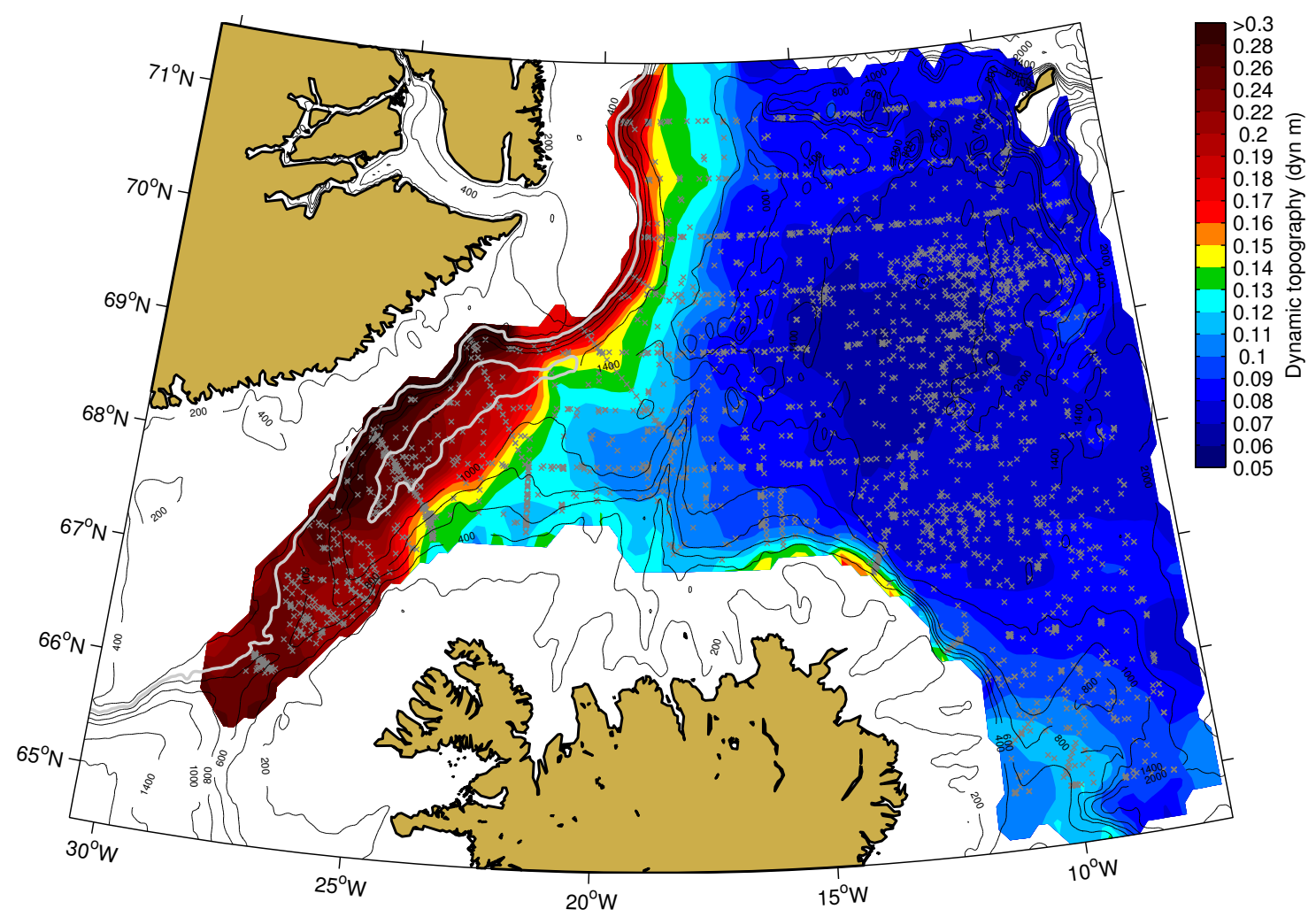

Figure 9: Dynamic height of the surface relative to $500 \mathrm{db}$. The gray lines are the $500 \mathrm{~m}$ depth contour along the east Greenland shelf break and the closed $1400 \mathrm{~m}$ depth contour delineating the Blosseville Basin. The gray crosses mark the locations of data points. The $200 \mathrm{~m}, 400 \mathrm{~m}, 600 \mathrm{~m}, 800 \mathrm{~m}, 1000 \mathrm{~m}, 1400 \mathrm{~m}$, and $2000 \mathrm{~m}$ isobaths are contoured as black lines.

water transported by the EGC in this region extends some distance offshore (Fig. 11). The temperature and salinity maxima indicate, however, that the core of the overflow water is found along the continental slope. (The strongest signature of the Atlantic-origin overflow water is found in the density range $27.9 \mathrm{~kg} / \mathrm{m}^{3}<\sigma_{\theta}<28.0 \mathrm{~kg} / \mathrm{m}^{3}$, used to isolate this water mass in Figure 11.) South of $69^{\circ} \mathrm{N}$, temperature and salinity maxima along the slope are no longer visible, and Atlanticorigin overflow water is observed throughout the Blosseville Basin. The hydrographic properties of the overflow water in this region have been modified, probably by the same process forming the separated EGC.

The historical hydrography supports the inference from the synoptic Kögur sections that the separated EGC is a permanent feature in the Blosseville Basin and that it provides a means of shelfbasin exchange impacting the circulation of both surface and overflow water masses north of the Denmark Strait. However, it is difficult to discern the details of how these water masses approach 

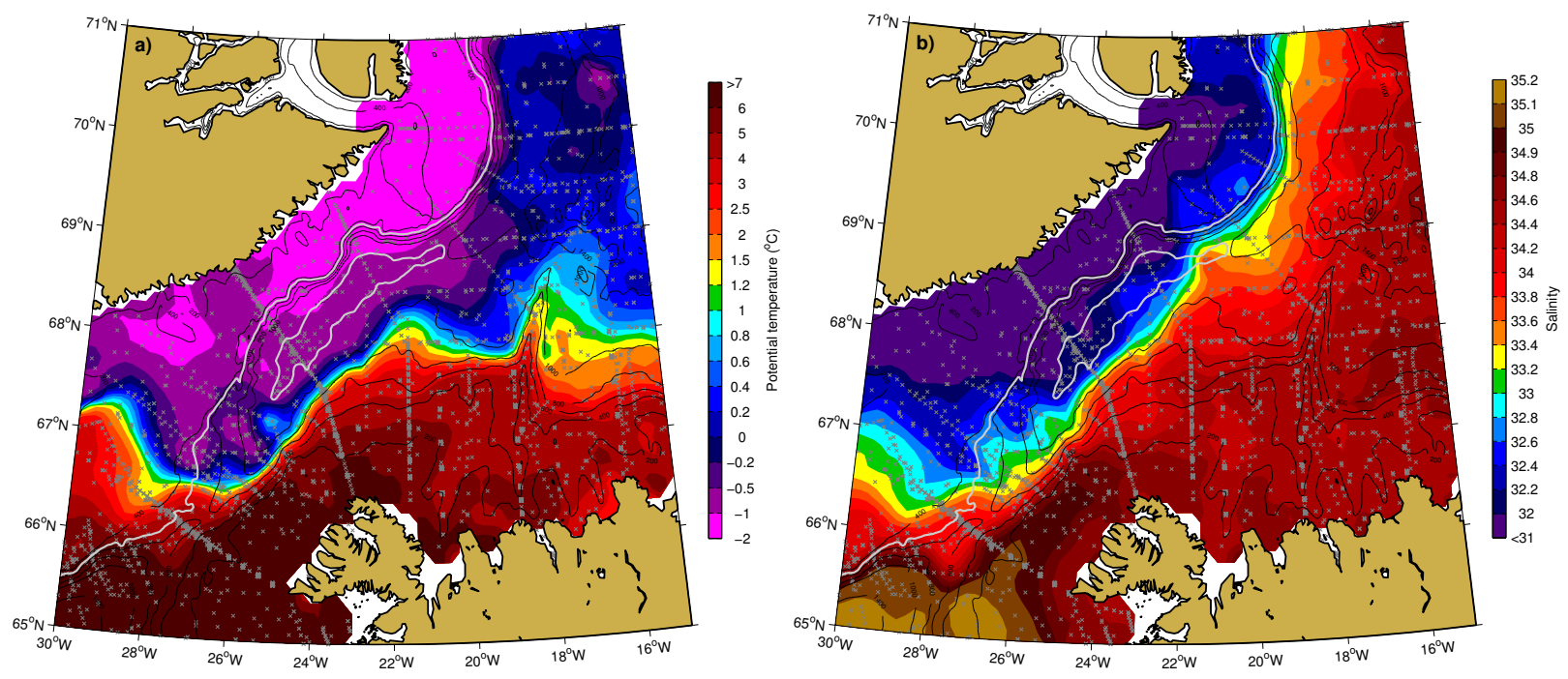

Figure 10: As in Figure 9, but for near-surface potential temperature (a, vertically averaged between 50 and $100 \mathrm{~m}$ ) and salinity (b, vertically averaged between 10 and $30 \mathrm{~m}$ ).
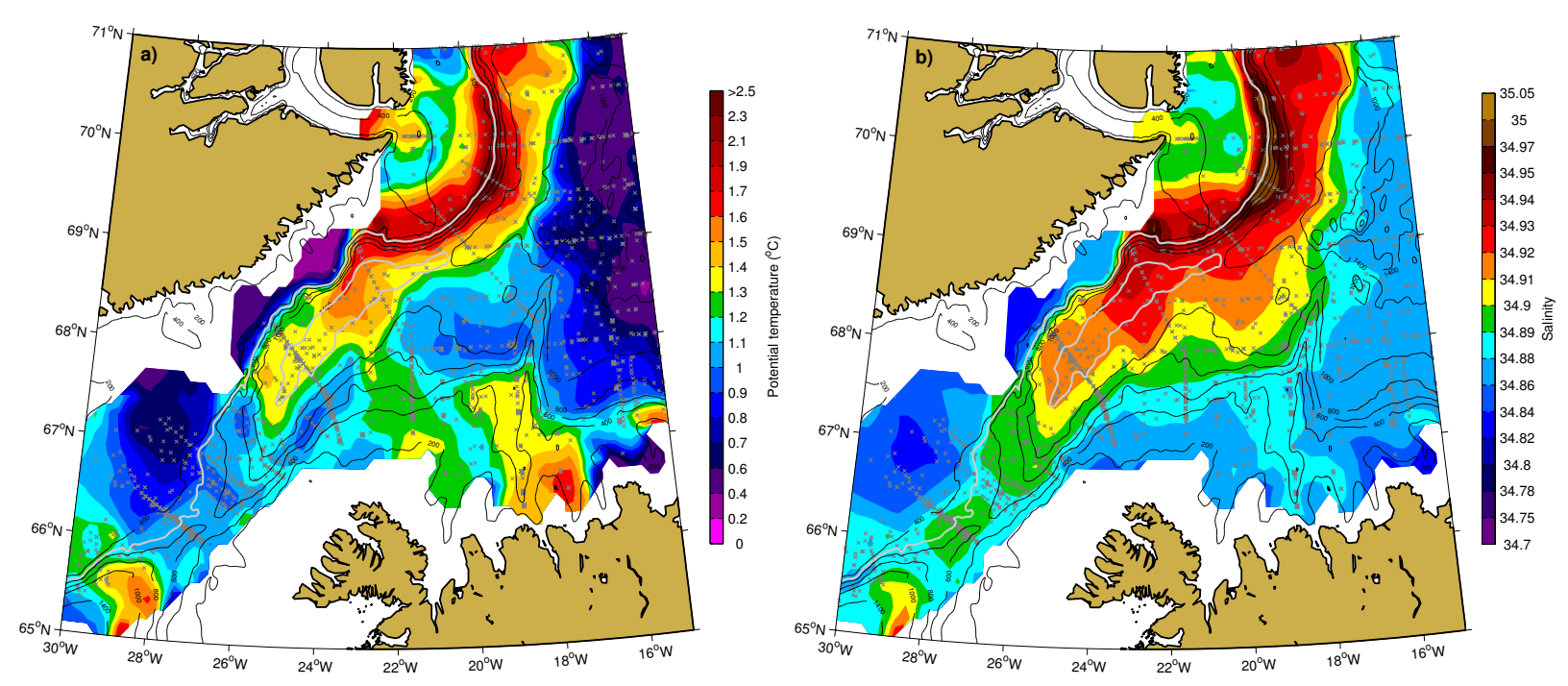

Figure 11: As in Figure 10, but for overflow waters (maximum value between 27.9 and $28.0 \mathrm{~kg} / \mathrm{m}^{3}$ ). 
and pass through the Denmark Strait from this analysis. In the vicinity of the sill warm, saline AW from the Irminger Current dominates the surface layer, even extending at times onto the Greenland shelf, and undiluted PSW appears to be found only near the coast. In the case of the overflow layer the two-branch EGC system and the NIJ, observed as distinct pathways at the Kögur transect near the southern end of the Blosseville Basin, merge prior to forming the DSOW plume exiting the Denmark Strait. The relative transports of these overflow pathways likely influence the final water mass composition of the plume (e.g. Rudels et al., 2003). In the next two sections we investigate the processes by which the separated EGC is formed, which will enable us to better understand the associated impacts on the overflow product and on the freshwater budget of the region.

\section{Atmospheric forcing}

The atmospheric circulation over the western subpolar North Atlantic is dominated by the Icelandic Low, a semi-permanent region of low pressure situated southwest of Iceland in the lee of southern Greenland (Serreze et al., 1997). The cyclonic circulation around the Icelandic Low and the associated positive wind stress curl can be seen in Figure 12. The curl attains its maximum value to the east of Greenland's southernmost point, Cape Farewell, as a result of the increased surface wind speeds in this region that are associated with westerly tip jets (Doyle and Shapiro, 1999; Moore and Renfrew, 2005; Våge et al., 2009). The low Froude number of the surface circulation, resulting from the high and steep topography of Greenland (Fig 12), leads to so called barrier winds along its east coast that are characterized by southerly flow directed parallel to the coast (Moore and Renfrew, 2005; Harden et al., 2011; Moore et al., 2012).

As can be seen from Figure 12a, surface wind speeds tend to be lowest near the coastline and over sea ice as a result of an increase in surface roughness (Moore, 2003; Petersen and Renfrew, 2009). Due to this reduction in wind speed from the nearshore ice, a narrow band of negative wind stress curl extends along the entire east coast of Greenland that is embedded in the generally positive wind stress curl of the broader subpolar North Atlantic (Fig. 12b). In the southeast portion of Greenland there are two regions of particularly steep coastal topography coupled with strong curvature of the coastline: One near $69^{\circ} \mathrm{N}$ and the other near $66^{\circ} \mathrm{N}$. The former is associated with the Watkins Range, that contains Greenland's highest mountain, and is in the vicinity of the Blosseville Basin. In these regions, there is an acceleration of the barrier winds because the flow is being forced to move around the obstacles (Harden and Renfrew, 2012; Moore, 2012). This localized flow distortion enhances the anti-cyclonic circulation. The combination of the lo- 
a)
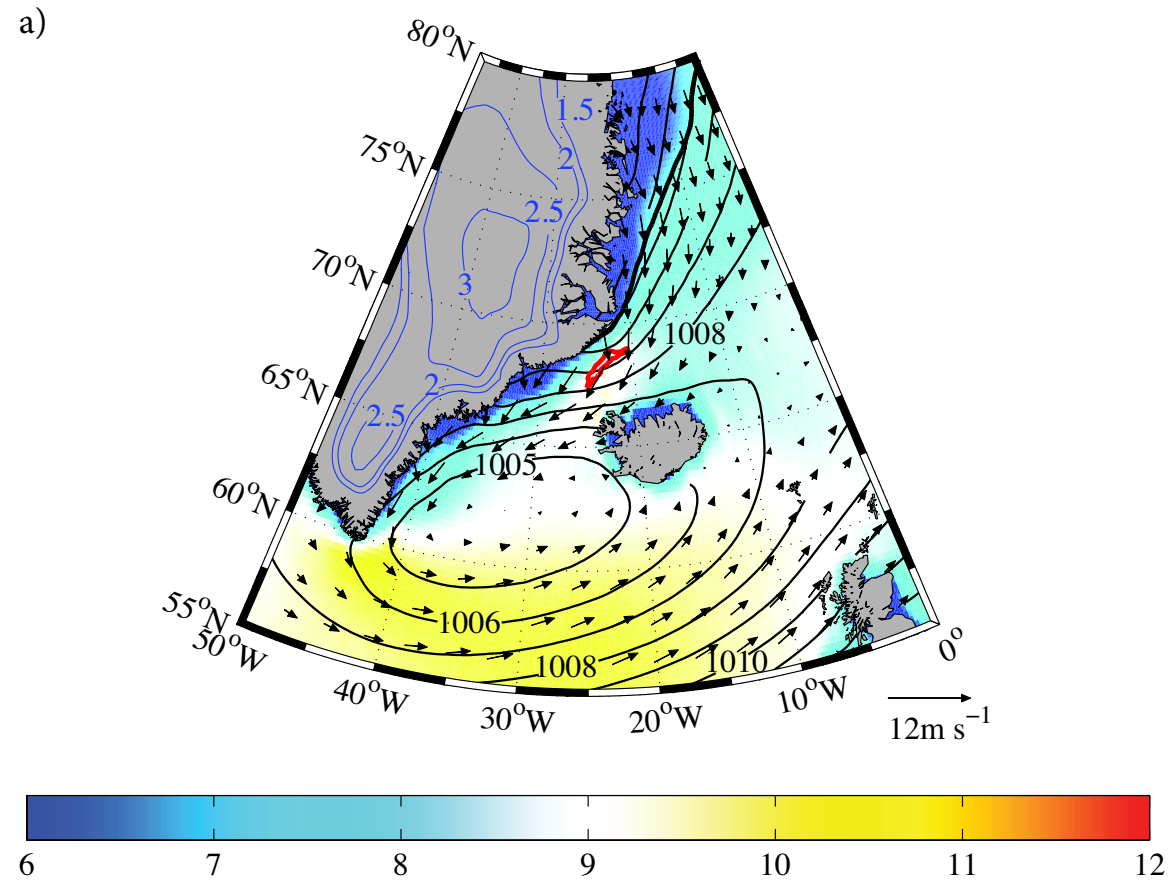

b)
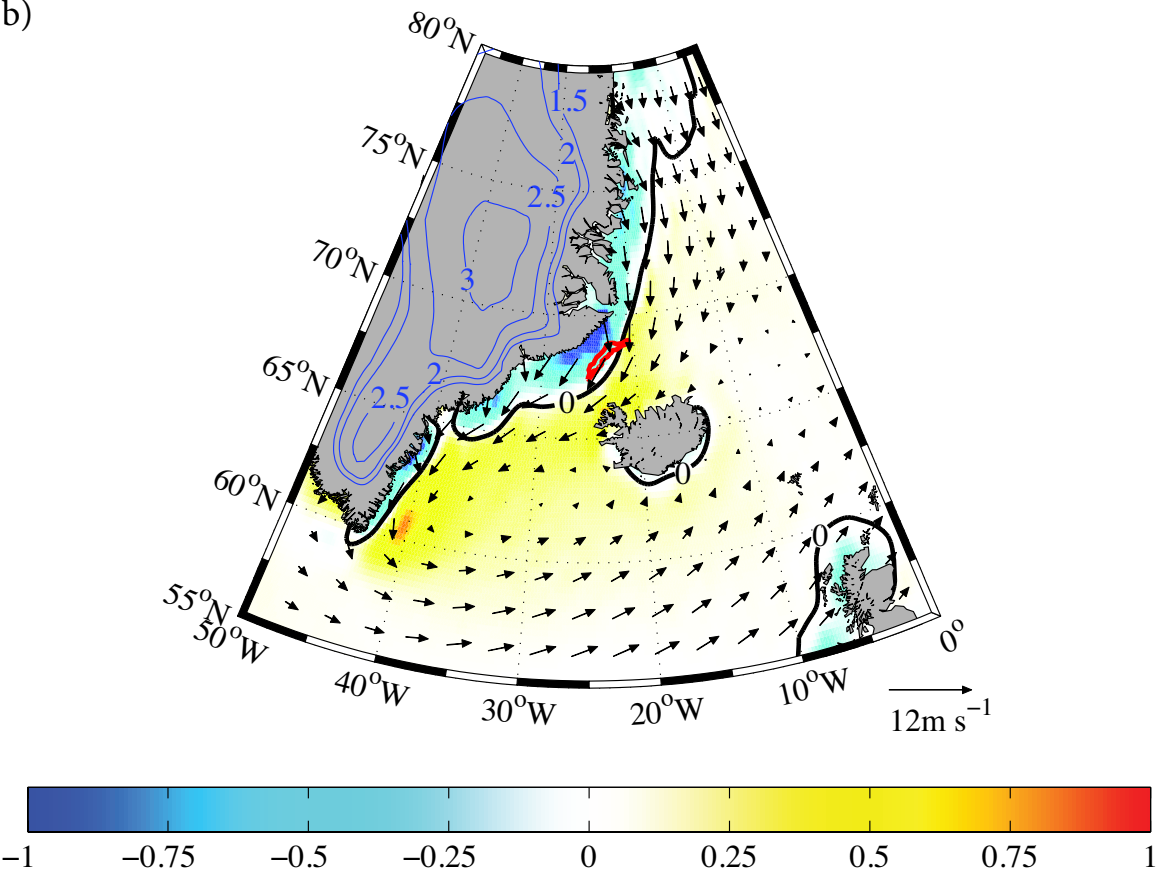

Figure 12: The annual mean (a) sea-level pressure (contours, mb), $10 \mathrm{~m}$ wind (vectors, m/s) and $10 \mathrm{~m}$ wind speed (color, $\mathrm{m} / \mathrm{s}$ ); and (b) curl of the wind stress (color, $10^{-6} \mathrm{~N} / \mathrm{m}^{2}$ ) and the $10 \mathrm{~m}$ wind (vectors, $\mathrm{m} / \mathrm{s}$ ) from the ERA-I for the period 1979-2011. In (a) the thick black line represents the annual mean 50\% sea ice concentration contour. In (b) the zero isoline of the curl of the wind stress is indicated by the thick black contour. The red contour delineates the approximate extent of the Blosseville Basin as represented by the $1400 \mathrm{~m}$ isobath. The blue contours represent the height of the topography over Greenland $(\mathrm{km})$. 
cal topographic steering together with the reduction in nearshore wind speed due to ice causes a particularly strong region of negative wind stress curl over the Blosseville Basin (Fig. 13).

The sea ice along east Greenland expands southwards during the winter and retreats northwards during the summer (Wadhams, 1981), and so the coastal region of low surface wind speed undergoes a similar cycle. Also, the Icelandic Low is deepest during the winter months and so the barrier winds are intensified during this period. Consequently, the negative wind stress curl over the Blosseville Basin is strongest in fall/winter (Fig. 13a) and weakest in spring/summer (Fig 13b). Note, however, that the curl remains negative even when the circulation is weak, and, as a result, the annual mean wind stress curl is negative in this region (Fig. 13c).

The strong negative wind stress curl over the Blosseville Basin, in conjunction with the closed bathymetric contours of the basin, is conducive for spinning up a local anti-cyclonic ocean gyre. The model simulation of Spall and Pickart (2003) demonstrated that positive wind stress curl east of Cape Farewell (Fig. 12b) was capable of driving the cyclonic Irminger Gyre (Våge et al., 2011a). This was true even though the wind forcing nearly vanishes during the summer months. The weak stratification of the Irminger Sea, in conjunction with the bathymetry of the continental slope, resulted in a "flywheel" effect whereby the seasonal input of vorticity from the atmosphere to the ocean was able to maintain a nearly steady gyre. At depth, the Blosseville Basin is characterized by similarly weak stratification adjacent to the continental slopes of Greenland and Iceland, and the atmospheric circulation imparts strong negative vorticity to the ocean for nearly half the year. As such, there is reason to suspect that an anti-cyclonic gyre should be maintained in the basin, consistent with the mean absolute geostrophic velocity section of Figure 4.

As demonstrated in the next section, there is an additional aspect of the wind forcing that appears to be of importance for the formation of the separated EGC. To first order the barrier winds parallel the shelf break of East Greenland, and, as such, there is an onshore Ekman transport in the surface layer. This shoreward flow helps maintain the hydrographic front associated with the shelf break EGC. As noted above, the sharp bend in the coastline near $69^{\circ} \mathrm{N}$ steers the wind towards the southwest (which is part of the reason for the negative wind stress curl over the Blosseville Basin). However, because the orientation of the continental slope changes so abruptly near $69^{\circ} \mathrm{N}$, the wind cannot adjust quickly enough to remain parallel to the shelf break at this location. This is demonstrated in Fig. 14 which documents the degree to which the wind parallels the $500 \mathrm{~m}$ isobath (roughly the shelf break) at each latitude in the domain of interest. One sees that at the northern end of the Blosseville Basin the winds are more than $40^{\circ}$ offset from the direction of the shelf 
a)

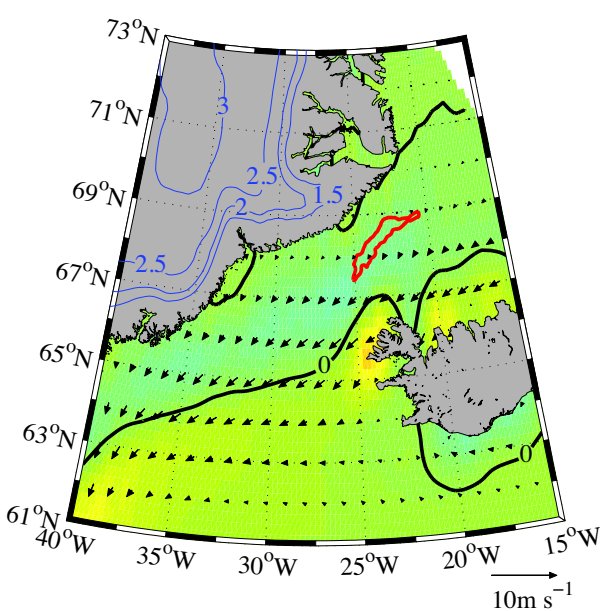

b)

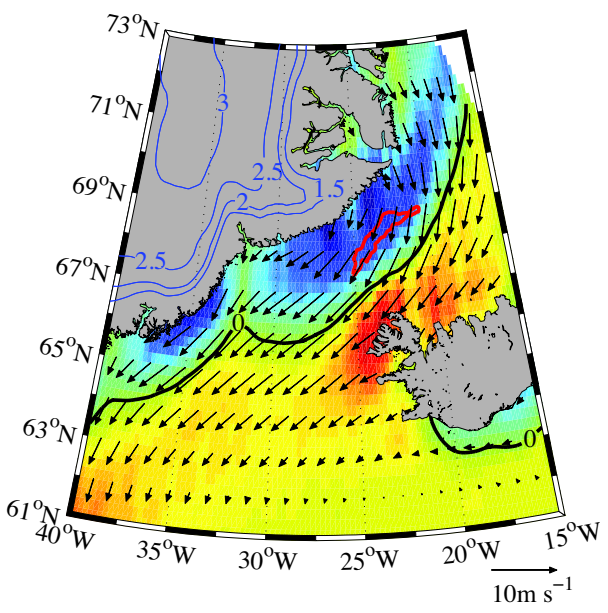

c)

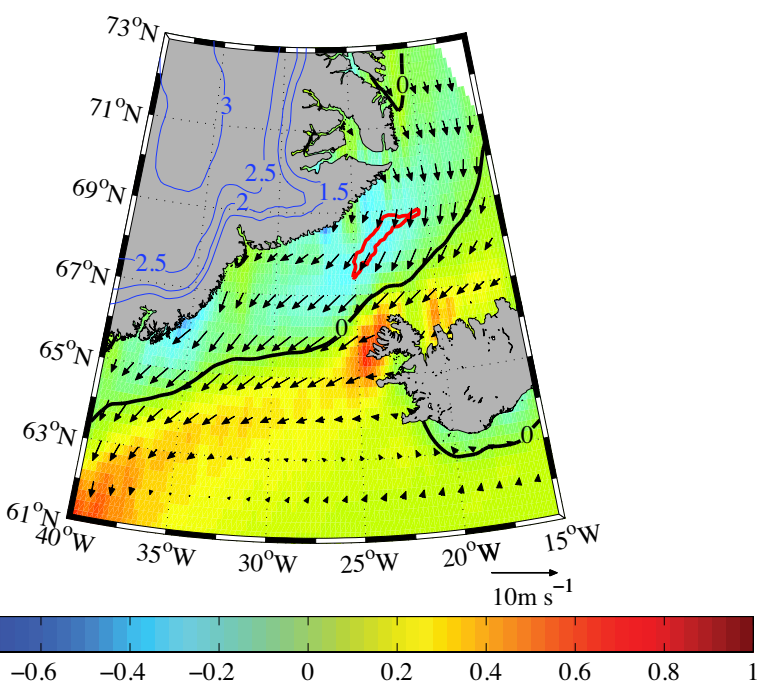

Figure 13: The curl of the wind stress (color, $10^{-6} \mathrm{~N} / \mathrm{m}^{2}$ ) and the $10 \mathrm{~m}$ wind (vectors, $\mathrm{m} / \mathrm{s}$ ) for (a) October; (b) June; and (c) the annual mean from the NARR for the period 1979-2011. The zero isoline of the curl of the wind stress is indicated by the thick black contour. The red contour delineates the approximate extent of the Blosseville Basin as represented by the $1400 \mathrm{~m}$ isobath. The blue contours represent the height of the topography over Greenland $(\mathrm{km})$. 


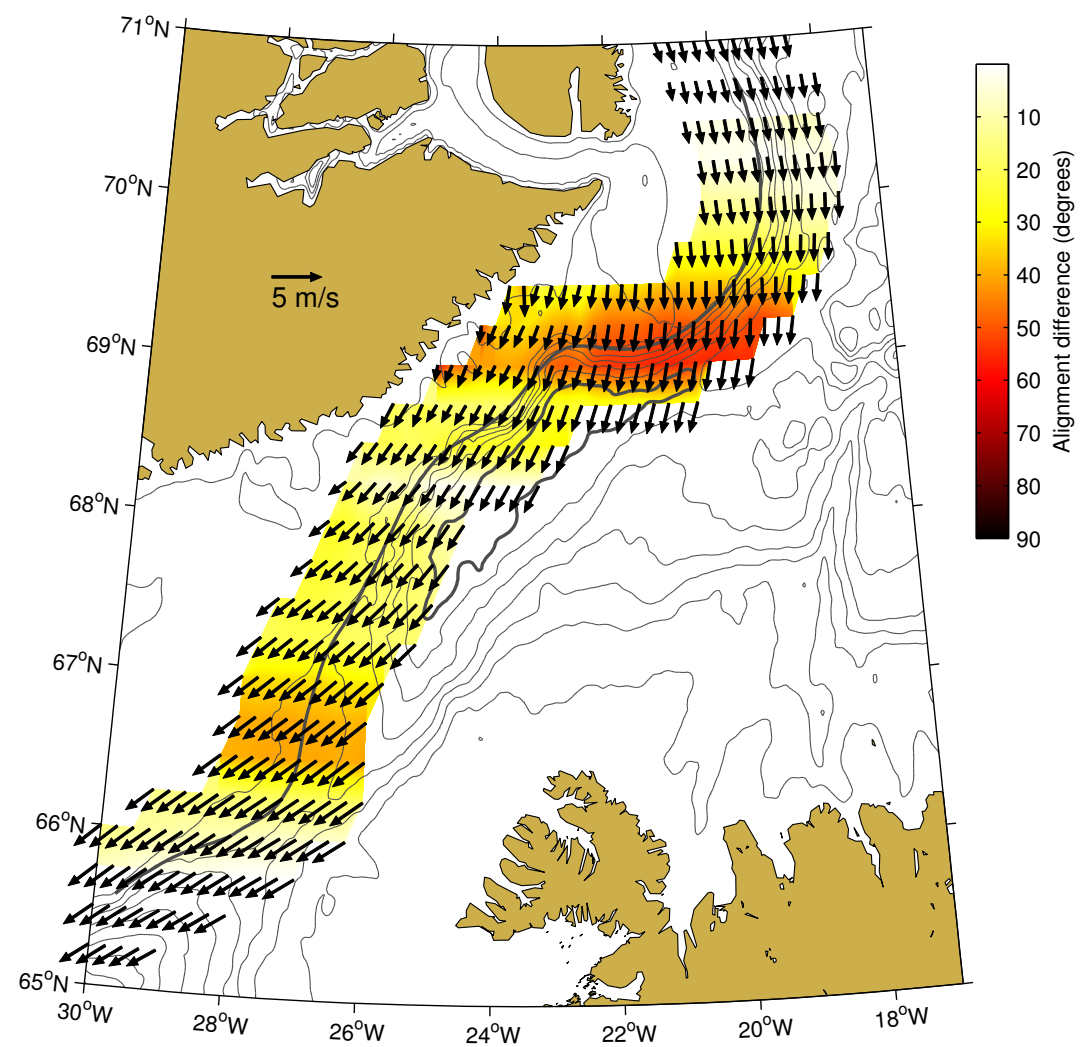

Figure 14: Difference in angle between the mean wind direction and orientation of the shelf break (color) as a function of latitude. The shelf break is taken to be the $500 \mathrm{~m}$ isobath, and the calculation is carried out along a $50 \mathrm{~km}$ swath centered around that isobath. The mean $10 \mathrm{~m}$ wind vectors from NARR, used in the calculation, are shown.

\section{Numerical simulation of the East Greenland Current north of the Denmark Strait}

We now use the idealized numerical model, described in Section 2.4, to examine the interaction between the East Greenland Current and the basin interior, and to investigate the cause of the separated EGC. In an effort to understand the most basic aspects of this interaction, we force the model with a steady wind stress (no surface forcing of heat and freshwater). The wind forcing is derived from the annual mean of the high resolution NARR product (Section 5), and the model has been run for a period of 2.5 years. The mean sea surface salinity over the final 2 years of integration is shown in Figure 15. There is a sharp gradient in salinity near the shelf break at high latitudes (although there is some spreading of saline waters onto the shelf between $y=500 \mathrm{~km}$ 


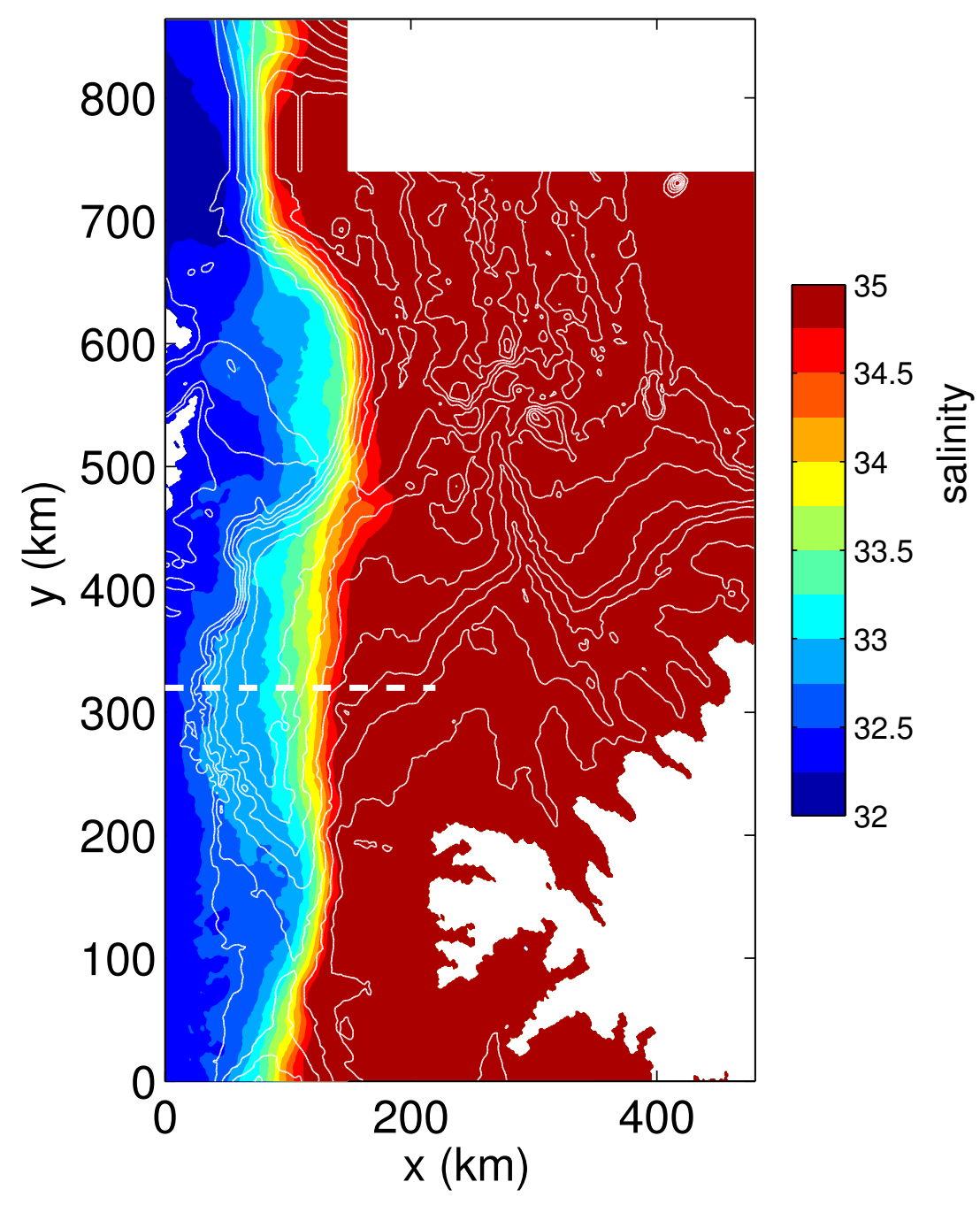

Figure 15: Mean sea surface salinity over final 2 years of integration, with bottom topography (white contours, contour interval $=200 \mathrm{~m}$ ). The dashed white line is the location of the vertical section in Figure 16.

and $700 \mathrm{~km}$ ). This gradient corresponds to a maximum in along-shelf velocity, i.e. a shelf break current. However, near $\mathrm{y}=500 \mathrm{~km}$ the freshwater begins to shift offshore of the shelf break such that by $\mathrm{y}=300 \mathrm{~km}$ waters fresher than 33.5 are found almost $100 \mathrm{~km}$ offshore of the shelf break. This freshwater remains offshore of the shelf edge all the way to the Denmark Strait (near $\mathrm{y}=100 \mathrm{~km}, \mathrm{x}=100 \mathrm{~km}$ in the model).

\subsection{Salinity and velocity}

A representative synoptic section of the along-channel velocity and salinity from the model at $\mathrm{y}=320 \mathrm{~km}$ are shown in Figure 16 for day 360 . This location roughly corresponds with the 
Kögur section. There is a maximum southward velocity of just over $1 \mathrm{~m} \mathrm{~s}^{-1}$ over the shelf break, which decreases towards the bottom (Fig. 16a). There is also southward flow exceeding $50 \mathrm{~cm} \mathrm{~s}^{-1}$ centered about $100 \mathrm{~km}$ offshore of the shelf break, over the eastern side of the Blosseville Basin. This flow is more surface trapped, with a vertical scale only on the order of $200 \mathrm{~m}$. In between these two southward flows is a northward current of $50 \mathrm{~cm} \mathrm{~s}^{-1}$ near $\mathrm{x}=80 \mathrm{~km}$. While it is tempting to associate the southward flow above the Iceland continental slope with the separated EGC, the two oppositely flowing jets in the interior are in fact the signature of an anti-cyclonic ring of shelf water that separated from the shelf and carried freshwater across the Blosseville Basin (Fig. 16b). This structure is reminiscent of some of the synoptic sections along the Kögur line (e.g. Figs. 5c and $6 \mathrm{c}$ ) and suggests that the features seen in the data may be large anti-cyclonic rings of shelf water (i.e. larger than the deformation radius).

The sea surface salinity on day 770 (Fig. 17) demonstrates that the shelf break jet south of $\mathrm{y}=500 \mathrm{~km}$ is very time-dependent, and is dominated by meanders and eddies with horizontal scales of $O(50 \mathrm{~km})$. These freshwater eddies penetrate well off the boundary, giving rise to the offshore shift in the mean position of the sea surface salinity front. The region between the shelf break and the eastern side of the Blosseville Basin is highly time dependent and dominated by eddies and filaments.

The spin-up of the offshore front, and the space and time scales of the variability, are demonstrated by a plot of along-channel velocity and salinity at $17.5 \mathrm{~m}$ depth as a function of $\mathrm{x}$ and time (Fig. 18). The fresh water initially confined to the shelf spreads rapidly offshore until around day 200, when the offshore front equilibrates near $\mathrm{x}=120 \mathrm{~km}$. Coincident with this salinity gradient is a region of southward flow with strength $O\left(10-20 \mathrm{~cm} \mathrm{~s}^{-1}\right)$. There is also a region of stronger southward flow shoreward of $x=50 \mathrm{~km}$, which is the meandering shelf break jet. The region between the shelf break jet and the offshore front is dominated by flow reversals of $O\left(20 \mathrm{~cm} \mathrm{~s}^{-1}\right)$. They generally occur in concert with southward flow farther offshore, separated by a freshwater anomaly. This is the signature of freshwater lenses that have been shed from the boundary current and have propagated offshore, as seen in Figures 16 and 17. The dashed line at day 360 in Figure 18 shows that the features seen in the synoptic section (Fig. 16) are quite common.

The model suggests then that the separated EGC arises from eddies that coalesce when they encounter the Iceland continental slope. In this scenario the northward flow between the shelf break EGC and separated EGC is simply the recirculation associated with freshwater eddies shed from 

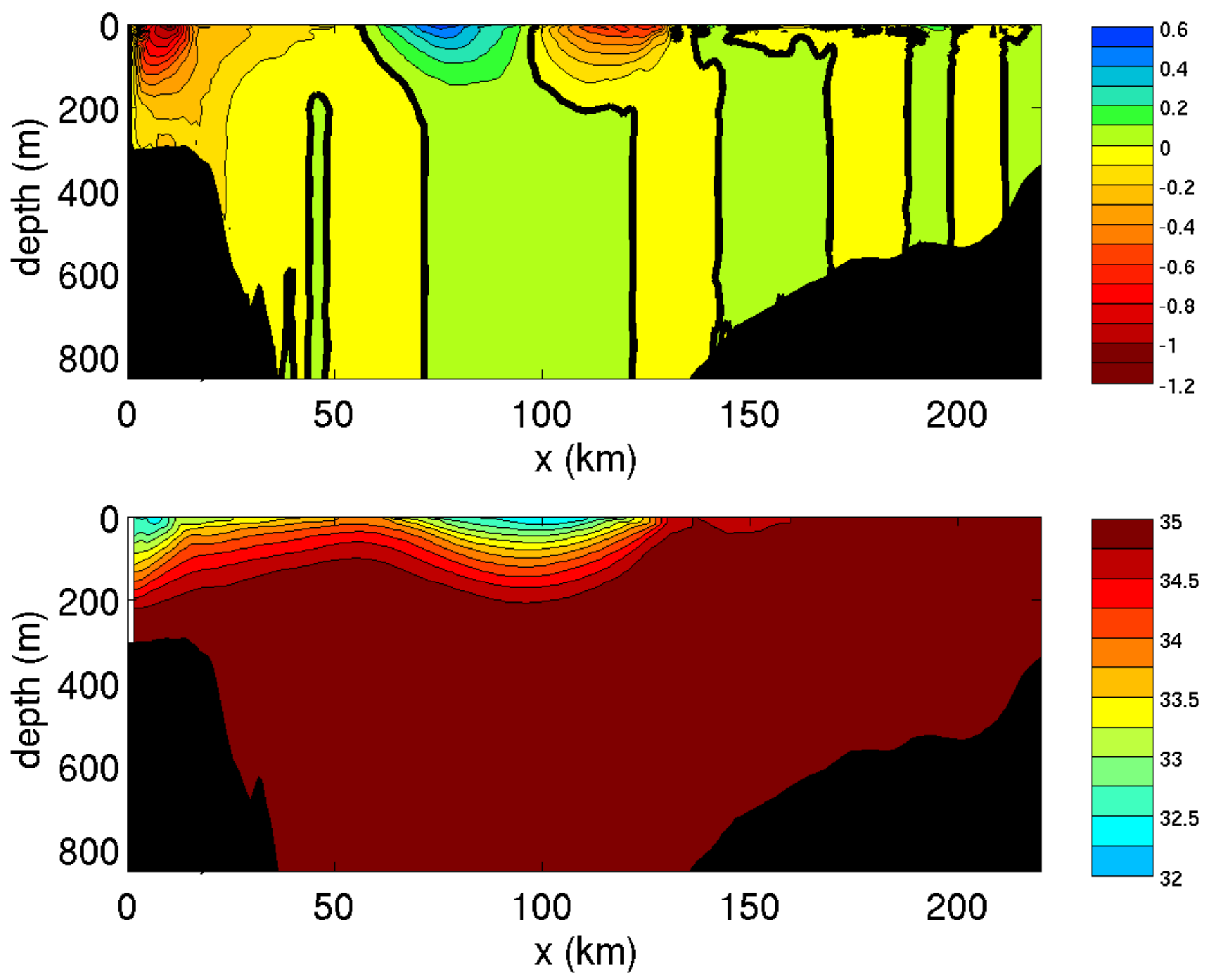

Figure 16: Synoptic zonal sections of meridional velocity (upper panel, c.i. $=0.1 \mathrm{~m} \mathrm{~s}^{-1}$, bold line is the zero velocity contour) and salinity (lower panel, c.i. $=0.25$ ) on day 360 .

the shelf break jet. Furthermore, the model suggests that synoptic sections across the Blosseville Basin should occasionally reveal isolated anti-cyclonic eddies, which, as noted above, seems to be the case. The alternate hypothesis of a wind-driven anti-cyclonic gyre, where the offshore branch is the separated EGC, is not supported by the model. ${ }^{3}$ However, one must keep in mind that the data are spatially and temporally sparse, which makes it difficult to distinguish between these two

${ }^{3}$ Note that the model does have anti-cyclonic wind stress curl over the Blosseville Basin (Fig. 13c). 


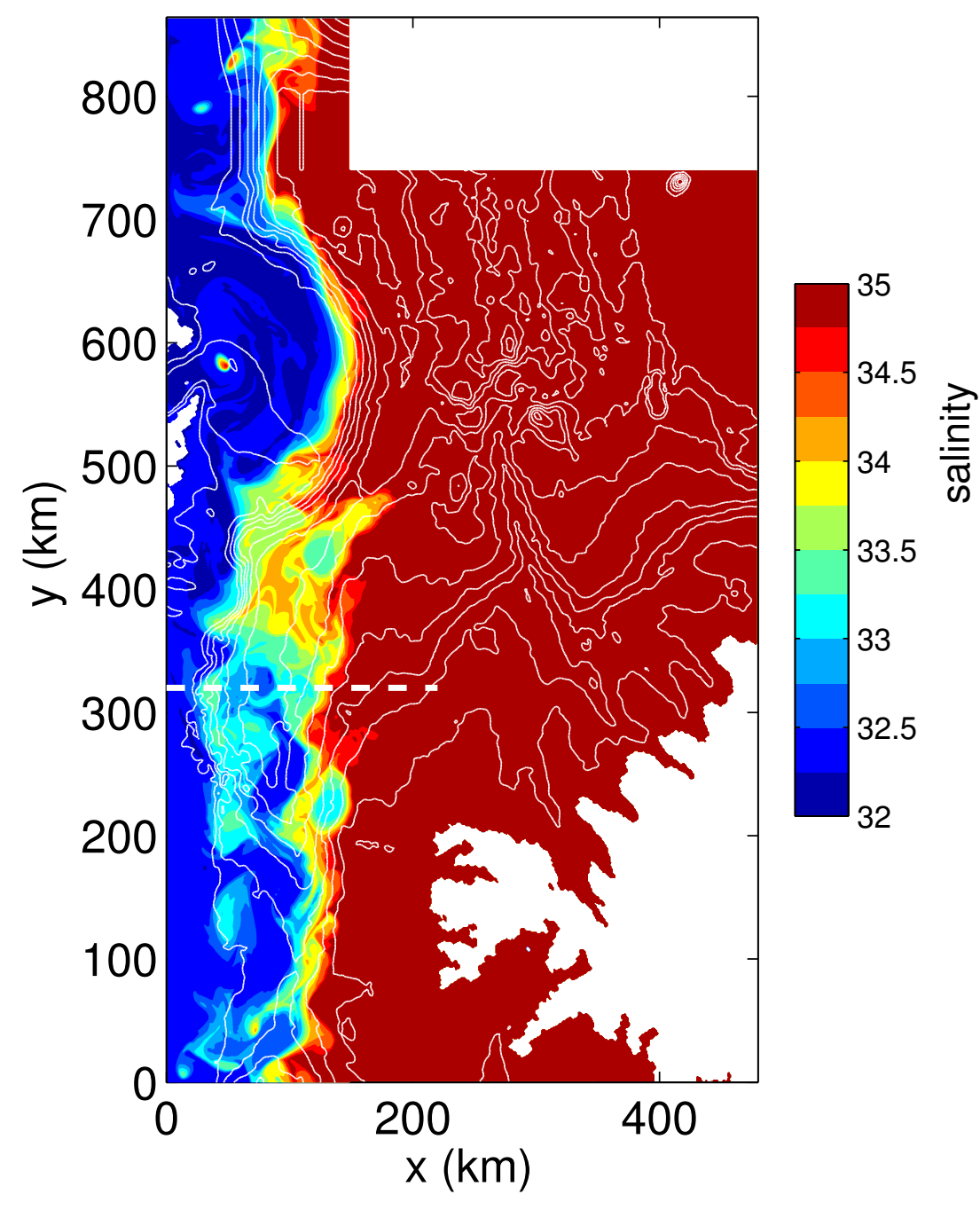

Figure 17: Sea surface salinity on day 770, with bottom topography (white contours, c.i. = $200 \mathrm{~m}$ ).

possibilities; a definitive conclusion will require more field data.

\subsection{Role of the wind}

Although the curl of the wind stress seems not to play a central role in the model, the wind stress itself is important in maintaining the shelf break jet and in determining where the freshwater is able to penetrate offshore of the boundary. A calculation was run with the same initial conditions and restoring but with no wind stress. Freshwater extends farther offshore than for the case with wind (not shown). As noted earlier, for the most part the wind is parallel to the coast (Fig. 14), so the Ekman transport is directed onshore. This advects dense, saline water towards the shelf break 

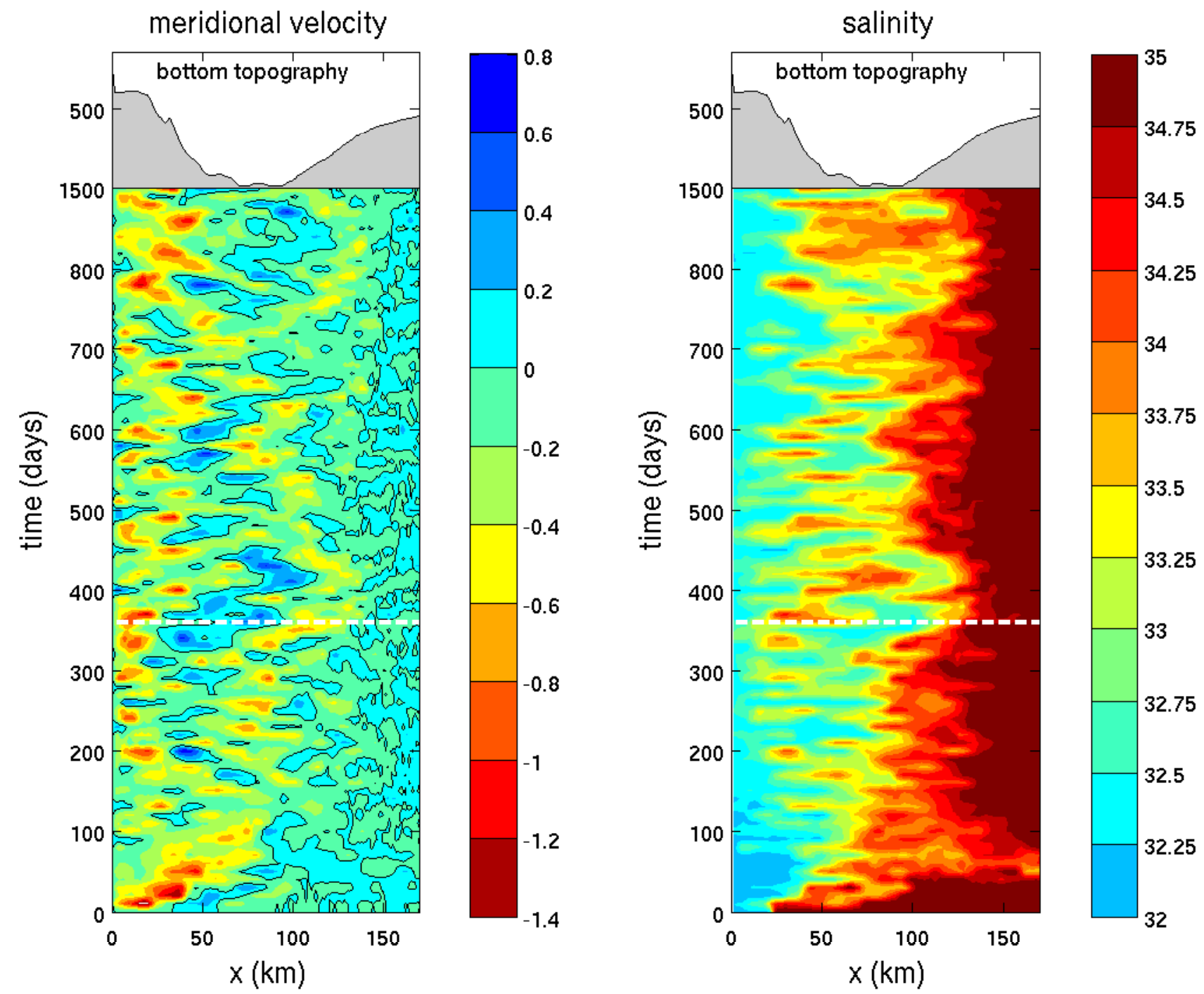

Figure 18: Time/x plots of meridional velocity (left panel, c.i. $=0.1 \mathrm{~m} \mathrm{~s}^{-1}$, bold line is the zero velocity contour) and salinity (right panel, c.i. $=0.25$ ) at $20 \mathrm{~m}$ depth and $\mathrm{y}=320 \mathrm{~km}$. The bottom topography at this location is indicated at the top. The dashed white line is day 360, when the sections in Figure 16 were taken.

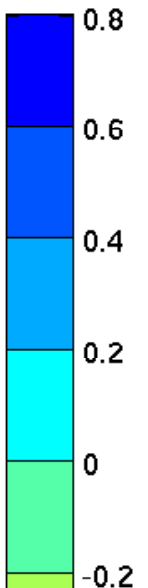

$-0.4$

$-0.6$

$-0.8$

$-1.2$

$-1.4$

6

4

2

8


averaged between 10 and $540 \mathrm{~m}$ depth. For the case with wind forcing, the average conversion rate is positive at about $1.2 \times 10^{-8} \mathrm{~m}^{2} \mathrm{~s}^{-3}$. This corresponds with eddy formation via baroclinic instability. The case with no wind starts at a level above the case with wind forcing, but rapidly decreases by about an order of magnitude. This weak level of energy conversion persists for the remainder of the calculation. This is consistent with the model result that, in the absence of wind, the early growth of instabilities spreads the freshwater more effectively over the basin interior, reducing the potential energy in, and instability of, the shelf break front. In contrast, when the wind is present the shelf break front is maintained by a local balance between frontogenesis by onshore Ekman transport and frontolysis by baroclinic instability. This allows for a more continued extraction of energy by the eddies from the front.

The influence of the Ekman transport on the offshore transport of freshwater is further demonstrated by calculations with an idealized coastline. In this scenario, the shelf topography is represented by two straight regions offset by $80 \mathrm{~km}$ (Fig. 19). The first bend in the continental slope, near $650 \mathrm{~km}$, is meant to represent the change in the orientation of the East Greenland shelfbreak near $69^{\circ} \mathrm{N}$ (Fig. 2), whereas the second bend farther to the south (in the opposite direction) is necessary to smoothly join the upper and lower boundaries of the model (as was done for the earlier model). The initial conditions for this simulation were specified the same as for the cases described above, and no restoring of salinity was used.

The sea surface salinity on day 100 is shown for a case with a uniform meridional wind stress of amplitude $-0.05 \mathrm{Nm}^{-2}$ (Fig. 19a) and for an otherwise identical calculation with no wind (Fig. 19b). The shelf break front develops meanders in both cases, but the offshore transport is confined to the region where the topography is not parallel to the wind stress for the case with wind, while it is more uniformly distributed along the shelf break jet in the absence of wind. This demonstrates the importance of the abrupt change in orientation of the boundary north of the Blosseville Basin and the fact that the wind cannot adjust quickly enough to remain parallel to the shelf break in this region (Fig. 14). Note that, for the case with wind, eddies also develop where the topography bends back to the east near $250 \mathrm{~km}$. This indicates that it is not simply inertial overshoot that causes the anti-cyclones to form at the northern end of the Blosseville Basin. Frontal instabilities are less inhibited where the Ekman transport is not perpendicular to the front, supporting the previous interpretation. One also sees in Figure 19 that the salinity front is located farther offshore everywhere in the case with no wind, which is consistent with the previous model results using the realistic topography and wind stress. 

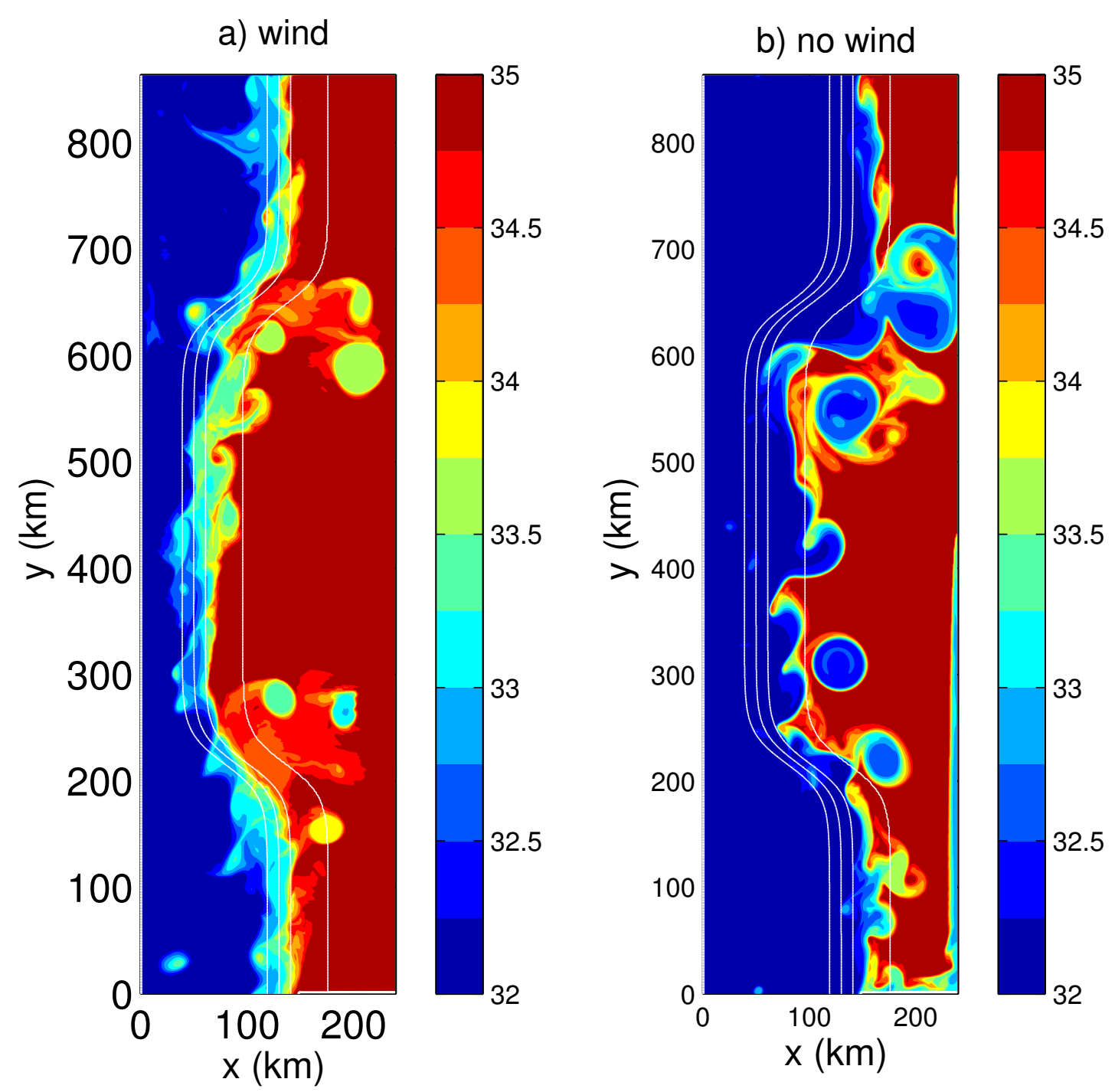

Figure 19: Sea surface salinity (color) on day 100 for an idealized shelf. The white contours indicate the bathymetry. a) The case of uniform meridional wind stress of $-0.05 \mathrm{Nm}^{-2}$. b) The case of no wind. The offshore freshwater flux is enhanced in the two regions where the wind is not parallel to the shelfbreak in a) compared to the case with no wind in b). 


\section{Discussion}

Our results show that the separated EGC provides a means for transporting freshwater as well as overflow water from the western boundary into the interior of the Blosseville Basin. What is the fate of the freshwater? Two direct pathways of freshwater export from the EGC into the interior Nordic seas, the Jan Mayen and East Icelandic currents, have been previously identified (e.g. Dickson et al., 2007). While the Jan Mayen Current is to some extent topographically steered by the Jan Mayen Fracture Zone (Bourke et al., 1992), Figure 2 shows no corresponding bathymetric feature farther south that would cause the East Icelandic Current to diverge from the EGC. Sparse current meter measurements at the Kögur transect led Jónsson (1999) to conclude that a partial recirculation of the EGC in the Denmark Strait was not the source of the East Icelandic Current and that it instead originates north of the transect. The East Icelandic Current has been traced upstream only as far as the Spar Fracture Zone (a gap in the Kolbeinsey Ridge north of Iceland, Fig. 2; Jónsson, 2007; Jónsson and Valdimarsson, 2012a). It is possible then that the mechanism generating the separated EGC in the northern part of the Blosseville Basin is also the source of freshwater to the East Icelandic Current. If so, a portion of the freshwater exported off the Greenland shelf in the Blosseville Basin would be advected by the East Icelandic Current into the Iceland Sea. The resulting reduction in surface salinity and increase in stratification could in turn reduce the extent of wintertime convection in the Iceland Sea Gyre, with possible consequences for the AMOC. Another ramification of the freshwater export from the boundary is that less of the undiluted PSW remains within the shelf break EGC equatorward of the Denmark Strait (Fig. 10) which could potentially impact the convective regions in the Irminger and Labrador seas.

Our revised circulation scheme is shown schematically in Figure 20. Included in the figure are findings from the present study as well as results from the study of Våge et al. (2011b). As seen in the schematic, and at odds with the Mauritzen (1996) circulation scheme, the source waters of the Denmark Strait Overflow Water plume primarily approach the sill along the Iceland continental slope. These waters are advected in roughly equal proportions by the separated EGC and the North Icelandic Jet (NIJ). By contrast, the shelf break EGC appears to transport a significantly smaller fraction (roughly 30\%) of overflow water along the Greenland slope. This is perhaps to be expected within the framework of hydraulic theory (e.g. Pratt, 2004). However, the NIJ originates far upstream (northeast of Iceland, Fig. 20) and the separated EGC transposes to the Iceland slope in the northern end of the Blosseville Basin, not due to shoaling bathymetry in the vicinity of the sill. At this point it remains uncertain how much water (if any) recirculates anti-cyclonically 


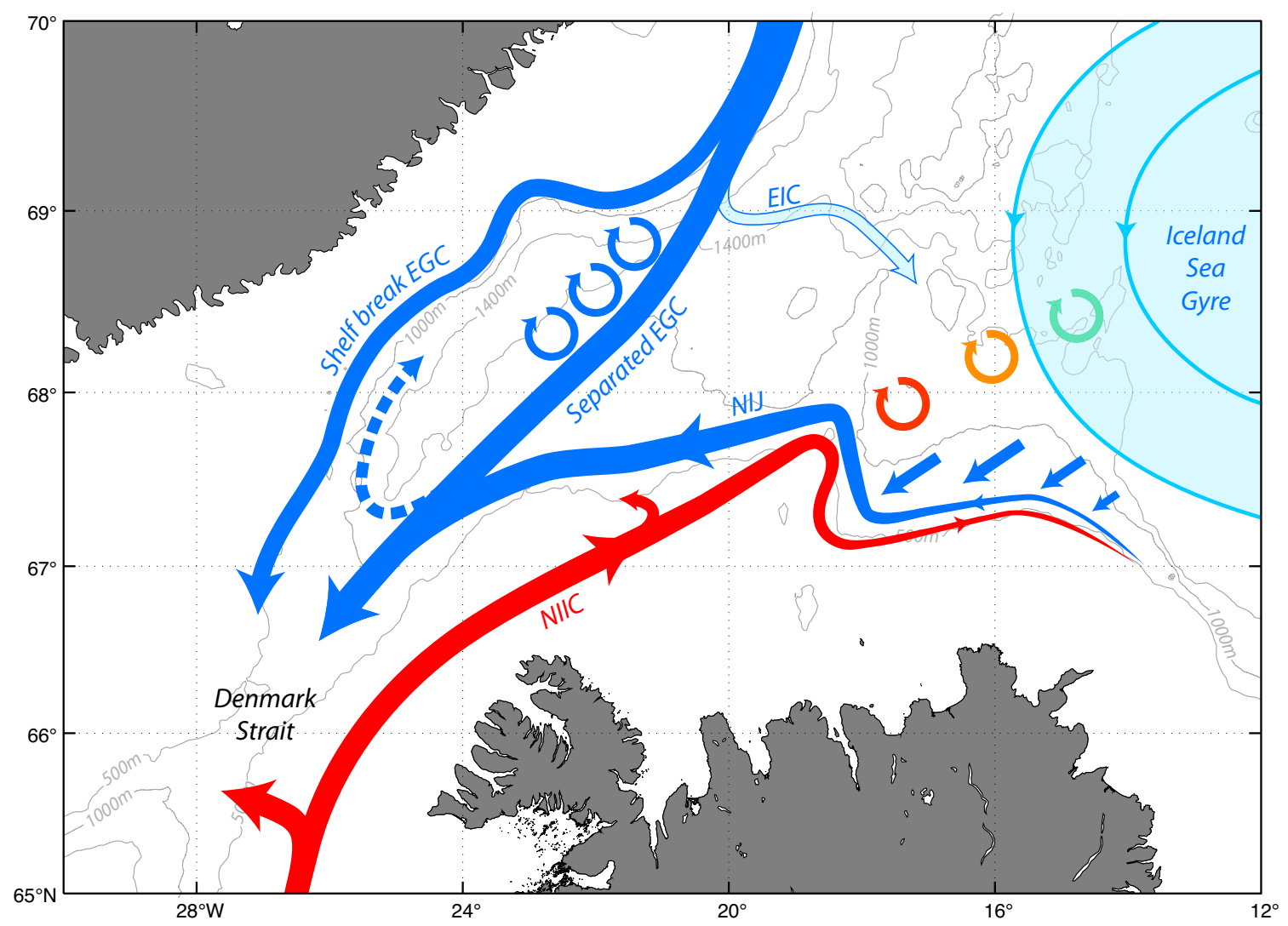

Figure 20: Schematic circulation in the area northeast of the Denmark Strait, presented in the text. The East Greenland Current (EGC) bifurcates north of the Blosseville Basin and the offshore branch joins with the North Icelandic Jet (NIJ) to provide most of the dense water feeding the Denmark Strait Overflow Water plume. The shelf break EGC provides the other portion. The separated EGC is believed to be formed by anti-cyclonic eddies that coalesce, with perhaps a wind-driven anti-cyclonic recirculation north of the sill (dashed line). As discussed in Våge et al. (2011b), the NIJ represents the lower limb of a local overturning loop: The inflowing North Icelandic Irminger Current - advecting warm Atlantic Water - forms eddies that are cooled by the atmosphere and disintegrate in the Iceland Sea Gyre. The dense water so formed progresses back towards the boundary (represented by the short blue arrows) and sinks to form the NIJ. A possible pathway of the upper-layer East Icelandic Current (EIC) is indicated as well. 
from the separated EGC north of the sill or whether or not there is a permanent gyre within the Blosseville Basin. A recently deployed mooring array along the Kögur transect should shed light on this.

We note that the high-resolution numerical simulations of the flow north of the Denmark Strait in Köhl et al. (2007) have aspects that are similar to the circulation scheme presented here. For example, the EGC bifurcates upstream of the Blosseville Basin. However, the eastern branch of the EGC in their model flows southward along the Kolbeinsey Ridge and feeds the NIJ far upstream of the Denmark Strait, which is inconsistent with our results. Nonetheless, Köhl et al. (2007)'s simulations indicate that most of the overflow water in the East Greenland Current switches from the Greenland to the Iceland slope at the northern end of the Blosseville Basin and that the overflow water primarily approaches the Denmark Strait sill along the eastern boundary.

Between the Kögur transect and the Denmark Strait sill the three branches advecting overflow water (the shelf break EGC, separated EGC, and the NIJ) presumably merge to form the DSOW plume. For the NIJ and separated EGC, which are governed by different dynamics and transport different water masses (mid-depth intensified flow of Arctic-origin overflow water and surfaceintensified flow advecting Atlantic-origin overflow water, respectively), the merging process may lead to the generation of instabilities upstream of the sill (e.g. Fristedt et al., 1999). Such preexisting instabilities may subsequently be amplified during the descent of the overflow plume (e.g. Spall and Price, 1998).

At present it is unknown which, if any, of these flow branches feeding the DSOW plume exerts dominant control on the variability of the overflow. Numerical simulations suggest that changes in the EGC north of the strait impact the transport and composition of the overflow plume (Karcher et al., 2011; Hall et al., 2011). However, comparable studies remain to be undertaken for the recently discovered NIJ. The mooring array across the Kogur line includes instruments in all three branches, which may provide some insights along these lines. More detailed tracer studies will also add to our understanding of the dominant pathways and upstream sources of overflow water. We stress that the circulation scheme presented here needs further confirmation, particularly to elucidate the merging of the different overflow branches and the fate of the freshwater exported into the interior. 


\section{Acknowledgments}

Historical hydrographic data were provided by the Marine Research Institute, Iceland; Institute of Marine Research, Norway; the Faroese Fisheries Laboratory; and the Geophysical Institute, University of Bergen, Norway, through the NISE project, and obtained from the World Ocean Database (www.nodc.noaa.gov). Argo data were obtained from the GODAE (www.usgodae.org) data center. We thank Else Juul Green for extracting data from the ICES data base (www.ices.dk) and Jack Cook for providing Figures 1 and 20. Support for this work was provided by the Norwegian Research Council (KV), the European Union 7th Framework Programme (FP7 2007-2013) under grant agreement n.308299 NACLIM Project (KV), US National Science Foundation grants OCE-0959381 (RP, MS, DT) and OCE-0850416 (MS), and the Natural Sciences and Engineering Research Council of Canada (KM). This is publication A420 from the Bjerknes Centre for Climate Research.

\section{Appendix A. Removal of barotropic tides from the synoptic sections using a tidal model}

The most recent version of the Oregon State University Atlantic Ocean tidal model (Egbert et al., 1994; Egbert and Erofeeva, 2002) was used to remove the barotropic tidal component from the ADCP profiles prior to the construction of the absolute geostrophic velocity sections. The improvements relative to the previous version used by Våge et al. (2011b) are higher resolution $\left(1 / 30^{\circ}\right.$ vs. $\left.1 / 12^{\circ}\right)$ and more accurate bathymetry. Comparison between the two versions at the Kögur transect shows that the greatest difference is found in the western end of the section, primarily due to the improved representation of the Greenland continental shelf and slope. For the Iceland slope the difference is less pronounced. The mean absolute difference in the NIJ transport resulting from de-tiding using the two models was $0.1 \mathrm{~Sv}$, which is well within the overall transport error estimates. In particular, the value of NIJ transport for the October 2008 occupation quoted by Våge et al. (2011b) differs by only $0.03 \mathrm{~Sv}$ when the new tidal model is applied. Hence the results presented here using the new model are consistent with previously published results in terms of NIJ transport. A reduction in the error arising from the de-tiding is, however, not justified from an overall quantitative comparison between the tidal model and actual bottom depths along the Kögur transect. 


\section{Appendix B. Quality control and gridding of the historical hydrography}

While most of the data have been subject to preliminary quality control, additional checks were performed following the general procedure of previous studies (e.g. Skagseth and Mork, 2012). Temperature and salinity measurements outside the expected range of values in the Nordic seas (-2$20^{\circ} \mathrm{C}$ and 20-36, respectively) were discarded. Each profile was subsequently inspected for density inversions, and profiles containing an inversion exceeding $0.05 \mathrm{~kg} / \mathrm{m}^{3}$ were excluded (Rossby et al., 2009; Skagseth and Mork, 2012). (Profiles with a single data spike were included after the removal of the spike.) Finally, each profile was checked for outliers as follows. All profiles within an effective radius of $110 \mathrm{~km}$ around the station in question (approximately one degree of latitude) were identified. The effective radius is increased along isobaths in regions of large topographic gradients and takes into account the greater correlation length scales along the bottom topography, which is appropriate given the close alignment between the circulation in the Nordic seas and the bottom contours (e.g. Nøst and Isachsen, 2003). The radius was calculated following Davis (1998):

$$
r^{2}=\left|\mathbf{x}_{g}-\mathbf{x}_{o}\right|^{2}+\left|3 \lambda \frac{H_{g}-H_{o}}{H_{g}+H_{o}}\right|^{2} .
$$

The first term on the right hand side of (B.1) is the geographical distance between the profile to be checked (subscript g) and all other profiles (subscript o), and the second term is the increase in distance determined by the difference in bottom depths $(\mathrm{H})$. The topographic parameter $\lambda$ was set to $100 \mathrm{~km}$ (Lavender et al., 2005; Voet et al., 2010; Skagseth and Mork, 2012). A doubling in water depth between two profiles would lead to an increase in $r^{2}$ by $\lambda^{2}$. Bathymetric data were obtained from the ETOPO2 2-minute elevation data base and smoothed by convolution with a $20-\mathrm{km}$ Gaussian window. All of the profiles so identified were then vertically interpolated at $5 \mathrm{~m}$ intervals, and the mean and standard deviation of temperature and salinity calculated at each depth. If the profile in question contained data points at any depth that differed from the mean by more than six standard deviations, it was discarded.

For the present analysis, observations from the historical hydrographic data set of a given property at a given depth level were anisotropically interpolated onto a regular $0.2^{\circ}$ longitude by $0.1^{\circ}$ latitude grid using (B.1). For each grid point (subscript $\mathrm{g}$ ) the effective distance to each data point (subscript o) was calculated. The average value of all data points within an effective distance of $50 \mathrm{~km}$ or less, weighted by the inverse of the distance (profiles closer to the grid point than $1 \mathrm{~km}$ were weighted equally), was assigned to that grid point. Using an effective distance increased by the difference in barotropic potential vorticity $(\mathrm{PV}=f / \mathrm{H}$, where $f$ is the Coriolis parameter) 
instead of difference in depth (e.g. Böhme and Send, 2005) yielded qualitatively similar results. Finally, the gridded fields were smoothed by convolution with a $30 \mathrm{~km}$ Gaussian window.

\section{Bibliography}

\section{References}

Aagaard, K., Carmack, E. C., 1989. The role of sea ice and other fresh water in the Arctic circulation. Journal of Geophysical Research 94, 14485-14498.

Adcroft, A., Hill, C., Marshall, J., 1997. Representation of topography by shaved cells in a height coordinate ocean model. Monthly Weather Review 125, 2293-2315.

Böhme, L., Send, U., 2005. Objective analyses of hydrographic data for referencing profiling float salinities in highly variable environments. Deep Sea Research II 52, 651-664, doi:10.1016/j.dsr2.2004.12.014.

Bourke, R. H., Paquette, R. G., Blythe, R. F., 1992. The Jan Mayen Current of the Greenland Sea. Journal of Geophysical Research 97, 7241-7250.

Cooper, L. H. N., 1955. Deep water movements in the North Atlantic as a link between climate changes around Iceland and the biological productivity of the English Channel and the Celtic Sea. Journal of Marine Research 14, 347-362.

Davis, R. E., 1998. Preliminary results from directly measuring middepth circulation in the tropical and South Pacific. Journal of Geophysical Research 103, 24619-24639.

de Steur, L., Hansen, E., Gerdes, R., Karcher, M., Fahrbach, E., Holfort, J., 2009. Freshwater fluxes in the East Greenland Current: A decade of observations. Geophysical Research Letters 36, L23611, doi:10.1029/2009GL041278.

Dee, D. P., Uppala, S. M., Simmons, A. J., Berrisford, P., Poli, P., Coauthors, 2011. The ERAInterim reanalysis: configuration and performance of the data assimilation system. Quarterly Journal of the Royal Meteorological Society 137, 553-597, doi:10.1002/qj.828.

Dickson, R. R., Brown, J., 1994. The production of North Atlantic Deep Water: Sources, rates and pathways. Journal of Geophysical Research 99, 12319-12341. 
Dickson, R. R., Dye, S., Jónsson, S., Köhl, A., Macrander, A., Marnela, M., Meincke, J., Olsen, S., Rudels, B., Valdimarsson, H., Voet, G., 2008. The overflow flux west of Iceland: Variability, origins and forcing. In: Dickson, R. R., Meincke, J., Rhines, P. (Eds.), Arctic-Subarctic Ocean Fluxes: Defining the role of the northern seas in climate. Springer, Dordrecht, The Netherlands, pp. 443-474.

Dickson, R. R., Rudels, B., Dye, S., Karcher, M., Meincke, J., Yashayaev, I., 2007. Current estimates of freshwater flux through Arctic and subarctic seas. Progress in Oceanography 73, $210-230$.

Dodd, P. A., Heywood, K. J., Meredith, M. P., Naveira-Garabato, A. C., Marca, A. D., Falkner, K. K., 2009. Sources and fate of freshwater exported in the East Greenland Current. Geophysical Research Letters 36, L19608, doi:10.1029/2009GL039663.

Dodd, P. A., Rabe, B., Hansen, E., Falck, E., Mackensen, A., Rohling, E., Stedmon, C., Kristiansen, S., 2012. The freshwater composition of the Fram Strait outflow derived from a decade of tracer measurements. Journal of Geophysical Research 117, doi:10.1029/2012JC008011.

Doyle, J. D., Shapiro, M. A., 1999. Flow response to large-scale topography: The Greenland tip jet. Tellus 51, 728-748.

Egbert, G. D., Bennett, A. F., Foreman, M. G. G., 1994. TOPEX/Poseidon tides estimated using a global inverse model. Journal of Geophysical Research 99, 24821-24852.

Egbert, G. D., Erofeeva, S. Y., 2002. Efficient inverse modeling of barotropic ocean tides. Journal of Atmospheric and Oceanic Technology 19, 183-204.

Eldevik, T., Nilsen, J. E. Ø., Iovino, D., Olsson, K. A., Sandø, A. B., Drange, H., 2009. Observed sources and variability of Nordic seas overflow. Nature Geoscience 2, 406-410, doi:10.1038/NGEO518.

Fristedt, T., Hietala, R., Lundberg, P., 1999. Stability properties of a barotropic surface-water jet observed in the Denmark Strait. Tellus 51, 979-989.

Hall, S., Dye, S. R., Heywood, K. J., Wadley, M. R., 2011. Wind forcing of salinity anomalies in the Denmark Strait overflow. Ocean Science 7, 821-834, doi:10.5194/os-7-821-2011. 
Hansen, B., Østerhus, S., 2000. North Atlantic-Nordic Seas exchanges. Progress in Oceanography $45,109-208$.

Hansen, B., Østerhus, S., 2007. Faroe Bank Channel overflow 1995-2001. Progress in Oceanography 75, 817-856, doi:10.1016/j.pocean.2007.09.004.

Harden, B. E., Renfrew, I. A., 2012. On the spatial distribution of high winds off southeast Greenland. Geophysical Research Letters 39, L14806, doi:10.1029/2012GL052245.

Harden, B. E., Renfrew, I. A., Petersen, G. N., 2011. A climatology of wintertime barrier winds off southeast Greenland. Journal of Climate 24, 4701-4717, doi:10.1175/2011JCLI4113.1.

Holfort, J., Albrecht, T., 2007. Atmospheric forcing of salinity in the overflow of Denmark Strait. Ocean Science 3, 411-416.

Holfort, J., Hansen, E., Østerhus, S., Dye, S., Jónsson, S., Meincke, J., Mortensen, J., Meredith, M., 2008. Freshwater fluxes east of Greenland. In: Dickson, R. R., Meincke, J., Rhines, P. (Eds.), Arctic-Subarctic Ocean Fluxes: Defining the role of the northern seas in climate. Springer, Dordrecht, The Netherlands, pp. 263-287.

Holfort, J., Meincke, J., 2005. Time series of freshwater-transport on the East Greenland Shelf at $74^{\circ}$ N. Meteorologische Zeitschrift 14, 703-710, doi:10.1127/0941-2948/2005/0079.

Jeansson, E., Jutterström, S., Rudels, B., Anderson, L. G., Olsson, K. A., Jones, E. P., Jr., W. M. S., Swift, J. H., 2008. Sources to the East Greenland Current and its contribution to the Denmark Strait Overflow. Progress in Oceanography 78, 12-28, doi:10.1016/j.pocean.2007.08.031.

Jochumsen, K., Quadfasel, D., Valdimarsson, H., Jónsson, S., 2012. Variability of the Denmark Strait overflow: Moored time series from 1996-2011. Journal of Geophysical Research, in press.

Jones, E. P., Anderson, L. G., Jutterström, S., Swift, J. H., 2008. Sources and distribution of fresh water in the East Greenland Current. Progress in Oceanography 78, 37-44, doi:10.1016/j.pocean.2007.06.003.

Jónsson, S., 1999. The circulation in the northern part of the Denmark Strait and its variability. ICES report CM-1999/L:06, 9 pp. 
Jónsson, S., 2007. Volume flux and fresh water transport associated with the East Icelandic Current. Progress in Oceanography 73, 231-241, doi:10.1016/j.pocean.2006.11.003.

Jónsson, S., Valdimarsson, H., 2004. A new path for the Denmark Strait overflow water from the Iceland Sea to Denmark Strait. Geophysical Research Letters 31, L03305, doi:10.1029/2003GL019214.

Jónsson, S., Valdimarsson, H., 2005. Recent developments in oceanographic research in Icelandic waters. In: Caseldine, C., Russell, A., Harðardóttir, J., Knudsen, O. (Eds.), Iceland - Modern processes and past environments. Elsevier, pp. 79-92.

Jónsson, S., Valdimarsson, H., 2012a. Hydrography and circulation over the southern part of the Kolbeinsey Ridge. ICES Journal of Marine Science, doi:10.1093/icesjms/fss101.

Jónsson, S., Valdimarsson, H., 2012b. Water mass transport variability to the north Icelandic shelf, 1994-2010. ICES Journal of Marine Science, doi:10.1093/icesjms/fss024.

Karcher, M., Beszczynska-Möller, A., Kauker, F., Gerdes, R., Heyen, S., Rudels, B., 2011. Arctic Ocean warming and its consequences for the Denmark Strait overflow. Journal of Geophysical Research 116, doi:10.1029/2010JC006265.

Käse, R. H., Serra, N., Köhl, A., Stammer, D. B., 2009. Mechanisms for the variability of dense water pathways in the Nordic Seas. Journal of Geophysical Research 114, C01013, doi:10.1029/2008JC004916.

Kinder, T. H., Parrilla, G., 1987. Yes, some of the Mediterranean outflow does come from great depth. Journal of Geophysical Research 92, 2901-2906.

Köhl, A., 2010. Variable source regions of Denmark Strait and Faroe Bank Channel overflow waters. Tellus 62A, 551-568, doi:10.1111/j.1600-0870.2010.00454.x.

Köhl, A., Käse, R. H., Stammer, D. B., 2007. Causes of changes in the Denmark Strait Overflow. Journal of Physical Oceanography 37, 1678-1696.

Kwok, R., Cunningham, G. F., Pang, S. S., 2004. Fram Strait sea ice outflow. Journal of Geophysical Research 109, C01009, doi:10.1029/2003JC001785. 
Lavender, K. L., Owens, W. B., Davis, R. E., 2005. The mid-depth circulation of the subpolar North Atlantic Ocean as measured by subsurface floats. Deep Sea Research I 52, 767-785.

Marshall, J., Hill, C., Perelman, L., Adcroft, A., 1997. Hydrostatic, quasi-hydrostatic, and nonhydrostatic ocean modeling. Journal of Geophysical Research 102, 5733-5752.

Mauritzen, C., 1996. Production of dense overflow waters feeding the North Atlantic across the Greenland-Scotland Ridge. Part 1: Evidence for a revised circulation scheme. Deep Sea Research I 43, 769-806.

Mesinger, F., DiMego, G., Kalnay, E., Mitchell, K., Shafran, P. C., Coauthors, 2006. North American regional reanalysis. Bulletin of the American Meteorological Society 87, 343-360.

Moore, G. W. K., 2003. Gale force winds over the Irminger Sea to the east of Cape Farewell, Greenland. Geophysical Research Letters 30, 1894, doi:10.1029/2003GLO18012.

Moore, G. W. K., 2012. A new look at Greenland flow distortion and its impact on barrier flow, tip jets and coastal oceanography. Geophysical Research Letters, doi:10.1029/2012GL054017.

Moore, G. W. K., Pickart, R. S., Renfrew, I. A., 2008. Buoy observations from the windiest location in the world ocean, Cape Farewell, Greenland. Geophysical Research Letters 35, L18802, doi:10.1029/2008GL034845.

Moore, G. W. K., Renfrew, I. A., 2005. Tip jets and barrier winds: A QuikSCAT climatology of high wind speed events around Greenland. Journal of Climate 18, 3713-3725.

Moore, G. W. K., Renfrew, I. A., Pickart, R. S., 2012. Spatial distribution of air-sea heat fluxes over the sub-polar North Atlantic Ocean. Geophysical Research Letters 39, L18806, doi:10.1029/2012GL053097.

Nansen, F., 1912. Das Bodenwasser und die Abkühlung des Meeres. Internationale Revue der gesamten Hydrobiologie and Hydrographie Band V, 1-42.

Nilsen, J. E. Ø., Hátún, H., Mork, K. A., Valdimarsson, H., 2008. The NISE data set. Tech. Rep. 08-01, Faroese Fisheries Laboratory, Box 3051, Tórshavn, Faroe Islands.

Nilsson, J., Björk, G., Rudels, B., Winsor, P., Torres, D. J., 2008. Liquid freshwater transport and Polar Surface Water characteristics in the East Greenland Current during the AO-02 Oden expedition. Progress in Oceanography 78, 45-57, doi:10.1016/j.pocean.2007.06.002. 
Nøst, O. A., Isachsen, P. E., 2003. The large-scale time-mean ocean circulation in the Nordic Seas and Arctic Ocean estimated from simplified dynamics. Journal of Marine Research 61, 175-210.

Olsson, K. A., Jeansson, E., Tanhua, T., Gascard, J.-C., 2005. The East Greenland Current studied with CFCs and released sulphur hexafluoride. Journal of Marine Systems 55, 77-95.

Petersen, G. N., Renfrew, I. A., 2009. Aircraft-based observations of air-sea fluxes over Denmark Strait and the Irminger Sea during high wind speed conditions. Quarterly Journal of the Royal Meteorological Society 135, 2030-2045, doi:10.1002/qj.355.

Pickart, R. S., Torres, D. J., Fratantoni, P. S., 2005. The East Greenland Spill Jet. Journal of Physical Oceanography 35, 1037-1053.

Pratt, L. J., 2004. Recent progress on understanding the effects of rotation in models of sea straits. Deep Sea Research II 51, 351-369.

Renfrew, I. A., Petersen, G. N., Sproson, D. A. J., Moore, G. W. K., Adiwidjaja, H., Zhang, S., North, R., 2009. A comparison of aircraft-based surface-layer observations over Denmark Strait and the Irminger Sea with meteorological analyses and QuikSCAT winds. Quarterly Journal of the Royal Meteorological Society 135, 2046-2066, doi: 10.1002/qj.444.

Rossby, T., Ozhigin, V., Ivshin, V., Bacon, S., 2009. An isopycnal view of the Nordic Seas hydrography with focus on properties of the Lofoten Basin. Deep Sea Research I 56, 1955-1971, doi:10.1016/j.dsr.2009.07.005.

Rudels, B., Björk, G., Nilsson, J., Winsor, P., Lake, I., Nohr, C., 2005. The interaction between waters from the Arctic Ocean and the Nordic Seas north of Fram Strait and along the East Greenland Current: Results from the Arctic Ocean-02 Oden expedition. Journal of Marine Systems $55,1-30$.

Rudels, B., Eriksson, P., Buch, E., Budéus, G., Fahrbach, E., Malmberg, S.-A., Meincke, J., Mälkki, P., 2003. Temporal switching between sources of the Denmark Strait overflow water. ICES Marine Science Symposia 219, 319-325.

Rudels, B., Fahrbach, E., Meincke, J., Budéus, G., Eriksson, P., 2002. The East Greenland Current and its contribution to the Denmark Strait overflow. ICES Journal of Marine Science 59, 1133 1154. 
Segtnan, O. H., Furevik, T., Jenkins, A. D., 2011. Heat and freshwater budgets of the Nordic seas computed from atmospheric reanalysis and ocean observations. Journal of Geophysical Research 116, C11003, doi:10.1029/2011JC006939.

Serreze, M. C., Carse, F., Barry, R. G., Rogers, J. C., 1997. Icelandic Low cyclone activity: Climatological features, linkages with the NAO, and relationships with recent changes in the Northern Hemisphere circulation. Journal of Climate 10, 453-464.

Skagseth, Ø., Mork, K. A., 2012. Heat content in the Norwegian Sea, 1995-2010. ICES Journal of Marine Science, doi:10.1093/icesjms/fss026.

Spall, M. A., Pickart, R. S., 2003. Wind-driven recirculations and exchange in the Labrador and Irminger Seas. Journal of Physical Oceanography 33, 1829-1845.

Spall, M. A., Price, J. F., 1998. Mesoscale variability in Denmark Strait: The PV outflow hypothesis. Journal of Physical Oceanography 28, 1598-1623.

Stommel, H., Bryden, H., Mangelsdorf, P., 1973. Does some of the Mediterranean outflow come from great depth? Pure and Applied Geophysics 105, 879-889.

Sutherland, D. A., Pickart, R. S., 2008. The East Greenland Coastal Current: Structure, variability and forcing. Progress in Oceanography 78, 58-77, doi:10.1016/j.pocean.2007.09.006.

Swift, J. H., Aagaard, K., 1981. Seasonal transitions and water mass formation in the Iceland and Greenland seas. Deep Sea Research 28A, 1107-1129.

Swift, J. H., Aagaard, K., Malmberg, S.-A., 1980. The contribution of the Denmark Strait overflow to the deep North Atlantic. Deep Sea Research 27A, 29-42.

Tanhua, T., Olsson, K. A., Jeansson, E., 2005. Formation of Denmark Strait overflow water and its hydro-chemical composition. Journal of Marine Systems 57, 264-288.

Tanhua, T., Olsson, K. A., Jeansson, E., 2008. Tracer evidence of the origin and variability of Denmark Strait Overflow Water. In: Dickson, R. R., Meincke, J., Rhines, P. (Eds.), ArcticSubarctic Ocean Fluxes: Defining the role of the northern seas in climate. Springer, Dordrecht, The Netherlands, pp. 475-503. 
Våge, K., Pickart, R. S., Sarafanov, A., Knutsen, Ø., Mercier, H., Lherminier, P., Bersch, M., van Aken, H. M., Meincke, J., Quadfasel, D., Bacon, S., 2011a. The Irminger Gyre: Circulation, convection, and interannual variability. Deep Sea Research I 58, 590-614, doi:10.1016/j.dsr.2011.03.001.

Våge, K., Pickart, R. S., Spall, M. A., Valdimarsson, H., Jónsson, S., Torres, D. J., Østerhus, S., Eldevik, T., 2011b. Significant role of the North Icelandic Jet in the formation of Denmark Strait Overflow Water. Nature Geoscience 4, 723-727, doi:10.1038/NGEO1234.

Våge, K., Spengler, T., Davies, H. C., Pickart, R. S., 2009. Multi-event analysis of the westerly Greenland tip jet based upon 45 winters in ERA-40. Quarterly Journal of the Royal Meteorological Society 135, 1999-2011, doi: 10.1002/qj.488.

Voet, G., Quadfasel, D., Mork, K. A., Søiland, H., 2010. The mid-depth circulation of the Nordic Seas derived from profiling float observations. Tellus 62, 516-529, doi:10.1111/j.1600 0870.2010.00444.x.

Wadhams, P., 1981. The ice cover in the Greenland and Norwegian Seas. Reviews of Geophysics and Space Physics 19, 345-393.

Wong, A. P. S., Johnson, G. C., Owens, W. B., 2003. Delayed-mode calibration of autonomous CTD float profiling salinity data by $\theta$-S climatology. Journal of Atmospheric and Oceanic Technology 20, 308-318. 